\title{
Classe, cor e etnia nas legislações de compulsão ao trabalho na Amazônia: do Diretório ao fim dos Corpos de Trabalhadores (1755-1859)
}

\author{
Class, color and ethnicity in the laws of unfree labor in the Amazon: \\ from the Directory to the end of the Workers' Corps (1755-1859)
}

\section{Adalberto Paz*}

Resumo: Desde o final do século XVIII, diferentes administrações portuguesas e brasileiras se ocuparam em criar mecanismos de compulsão ao trabalho, voltados às populações não legalmente escravizadas na Amazônia. Após a abolição do cativeiro de povos indígenas, em 1755, sucessivas legislações buscaram estabelecer rígidas bases oficiais (não raramente exasperadas pelas práticas cotidianas de coerção) para que os pobres livres e libertos, sobretudo índios, negros e mestiços, fossem obrigados a realizar atividades laborais, tanto em serviços e obras públicas quanto para particulares. Esses trabalhadores eram empregados em funções econômicas fundamentais tais como transporte, extrativismo, lavoura, comércio, entre outros, num cenário em que a presença de escravos negros era significativamente menor do que em outras regiões do país. A partir disso, pretende-se analisar de que modo as autoridades públicas e agentes privados articularam formas legais visando impelir os pobres livres e libertos ao trabalho, e como tais instrumentos buscaram regular e naturalizar diferenças de origem étnicas e sociais objetivando a máxima retenção e controle de toda força de trabalho não escrava disponível na Amazônia no século XIX. Igualmente serão enfatizados os modos pelos quais essas populações vivenciaram, reagiram e se opuseram a tais investidas legais contra sua liberdade, mobilizando-se por meio de fugas, organizando-se politicamente em áreas de disputas fronteiriças e fazendo uso dos recursos naturais não apenas para sua

\footnotetext{
* Doutor em História pela Universidade Estadual de Campinas (Unicamp). Docente do Programa de Pós-Graduação em História da Universidade Federal do Amapá (UNIFAP). ORCID: https://orcid.org/0000-00025123-0362. E-mail: adalbertojrpaz@gmail.com.
} 
sobrevivência, mas também para a reafirmação da sua autonomia sociocultural e econômica.

Palavras-chave: Legislação e trabalho; trabalho não livre; Amazônia.

Abstract: Since the end of the 18th century, different Portuguese and Brazilian administrations have been concerning creating mechanisms of compulsion to work aimed at populations not legally enslaved in the Amazon. After the abolition of the captivity of indigenous peoples, in 1755, successive laws sought to establish rigid official bases (not infrequently exasperated by the daily practices of coercion) so that the free and freed poor, especially Indians, blacks and mestizos, were obliged to carry out work activities both in services and public works, as for private individuals. These workers were employed in fundamental economic functions such as transportation, extractivism, farming, trade, among others, in a scenario in which the presence of black slaves was significantly less than in other Brazilian regions. Based on this, we intend to analyze how public authorities and private agents articulated legal forms aiming at impelling the free and free poor to work, and how these instruments sought to regulate and naturalize ethnic and social differences aiming at maximum retention and control of all non-slave labor available in the Amazon in the 19th century. Equally, the ways in which these populations experienced, reacted and opposed such legal advances against their freedom will be emphasized, mobilizing through escapes, organizing politically in areas of border disputes and making use of natural resources not only for their survival, but also to reaffirm their sociocultural and economic autonomy.

Keywords: Legislation and labor; unfree labor; Amazon.

\section{Liberdade e escravidão na Amazônia setecentista: do Diretório à Carta Régia de 1798}

\footnotetext{
A DISPUTA PELO ACESSO e controle da força de trabalho dos subalternos foi um aspecto eminentemente crucial e dramático da história da Amazônia, ocasionando conflitos não apenas entre as classes, mas inclusive dissensões no interior da elite. Para muitos, a escravidão africana submetia os cativos aos desígnios de seus proprietários, e qualquer intervenção do Estado era uma intromissão em assuntos privados. Por outro lado, desde muito cedo, a apropriação do trabalho indígena engendrou regulações diversas. A ideia de "selvageria" dos nativos corroborou a criação de políticas e legislações que insistiam num modelo de incorporação social por etapas. Considerado incapaz ou em estado de barbárie, o índio necessitaria ser tutelado para que the fossem incutidos os dois principais valores da sociedade colonial: a devoção à fé católica e o trabalho socialmente útil. Nessas condições, foi estabelecido que o controle, o acesso e a distribuição da mão de obra indígena caberiam, primeiramente, aos eclesiásticos, passando, depois do século XVIII, a ser basicamente
} 
prerrogativa de outros agentes públicos (diretores de aldeamento, juízes, câmaras, militares), sendo facilitado cada vez mais o uso do trabalho indígena por particulares. ${ }^{1}$

Dessa forma, negros e índios passariam a desempenhar funções específicas na sociedade amazônica, sobretudo depois das reformas estruturais implementadas no século XVIII, durante a administração de Sebastião José de Carvalho e Melo, o marquês de Pombal. Buscando dinamizar aspectos econômicos da região, para adequá-los às práticas mercantilistas mundiais, e redefinindo hierarquias entre os sujeitos, para alargar a base de sustentação do projeto colonial, o ministro realizou medidas que afetaram diretamente as populações nativas, os negros e seus descendentes. Dentre elas, podemos destacar o incremento da agricultura comercial e de exportação, a ampliação do uso do trabalho escravo africano, a expulsão dos jesuítas e a transformação das antigas missões em vilas e lugares, com efeitos importantes em suas respectivas administrações, para citar apenas algumas. ${ }^{2}$

À parte os interessantes debates e polêmicas em torno dos eventuais sucessos ou fracassos econômicos do "período pombalino", ${ }^{3}$ não há dúvidas de que suas intervenções se notabilizaram por marcar um aprofundamento e aceleração dos impactos socioculturais colonizatórios sobre os índios da Amazônia. Principalmente, devido às determinações do chamado "Diretório dos Índios", legislação promulgada em 1757, que visava regular a vida civil de todos os indígenas, recém-proclamados súditos da Coroa portuguesa. ${ }^{4}$

Mas, visto de forma geral, no intervalo de aproximadamente meio século entre o setecentos e o oitocentos, era inegável que as reformas haviam ficado muito aquém das intenções em pelo menos dois aspectos. Na agricultura comercial, embora existissem áreas com algum destaque devido a produtos, como a cana-de-açúcar, arroz, cacau e algodão, principalmente nas cercanias de Belém, nas regiões dos rios Guamá, Capim, Acará e Tocantins, ${ }^{5}$

1 Sobre as diferentes formas de tutela e administração religiosa e civil do elemento indígena, visando a sua incorporação social e produtiva durante os períodos colonial e imperial, ver FARAGE, Nádia; CUNHA, Manuela Carneiro da. Caráter da tutela dos índios: origens e metamorfoses. In: CUNHA, Manuela Carneiro da. Os direitos dos índios: ensaios e documentos. São Paulo: Brasiliense, 1987, p. 103-117.

2 Sobre as políticas coloniais portuguesas à época de Sebastião José de Carvalho e Melo, ver MENDONÇA, Marcos Carneiro de. A Amazônia na Era Pombalina. Rio de Janeiro: Imprensa Nacional, 1963, 3 v. FALCON, Francisco José Calazans. A época pombalina. São Paulo: Ática, 1982. DIAS, Manuel Nunes. Fomento e mercantilismo: a Companhia Geral do Grão-Pará e Maranhão (1755-1778). Belém: UFPA, 1970, 2 v.

3 Um dos primeiros trabalhos acadêmicos a criticar a ideia de um considerável impulso de desenvolvimento amazônico, a partir das reformas pombalinas, foi CARDOSO, Ciro Flamarion. Economia e sociedade em áreas coloniais periféricas: Guiana Francesa e Pará (1750-1817). Rio de Janeiro: Graal, 1984. Para uma discussão historiográfica mais ampla, sobre as diferentes formas como a região foi interpretada por autores do século XIX ao XX, ver QUEIROZ, Jonas Marçal de; COELHO, Mauro Cesar. Fronteiras da História, limites do saber: a Amazônia e seus intérpretes. In: Amazônia: modernização e conflito (séculos XVIII e XIX). Belém: UFPA/NAEA; Macapá: UNIFAP, 2001, p. 157-190.

4 Sobre o período pombalino e os índios na Amazônia, ver ALMEIDA, Maria Regina Celestino de. Os Vassalos D’EI Rey nos confins da Amazônia: a colonização da Amazônia ocidental (1750-1798). Dissertação (mestrado em História) - Universidade Federal Fluminense, Niterói, 1990. ALMEIDA, Rita Heloísa de. O Diretório dos Índios: um projeto de "civilização" no Brasil do século XVIII. Brasília: Editora da Universidade de Brasília, 1997. DOMINGUES, Ângela. Quando os índios eram vassalos: colonização e relações de poder no Norte do Brasil na segunda metade do século XVIII. Lisboa: Comissão Nacional para as Comemorações dos Descobrimentos Portugueses, 2000. SAMPAIO, Patrícia Maria Melo. Espelhos partidos: etnia, legislação e desigualdade na colônia. Manaus: EDUA, 2011. COELHO, Mauro Cezar. Do sertão para o mar: um estudo sobre a experiência portuguesa na América, a partir da colônia: o caso do Diretório dos Índios (1751-1798). Tese (doutorado em História) - Faculdade de Filosofia, Letras e Ciências Humanas, Universidade de São Paulo, São Paulo, 2005.

5 Acerca dos empreendimentos, conflitos e movimentos sociais do rio Acará, ver MARIN, Rosa Elizabeth Acevedo. 
Imagem 1. Mapa geral da Amazônia no século XIX.

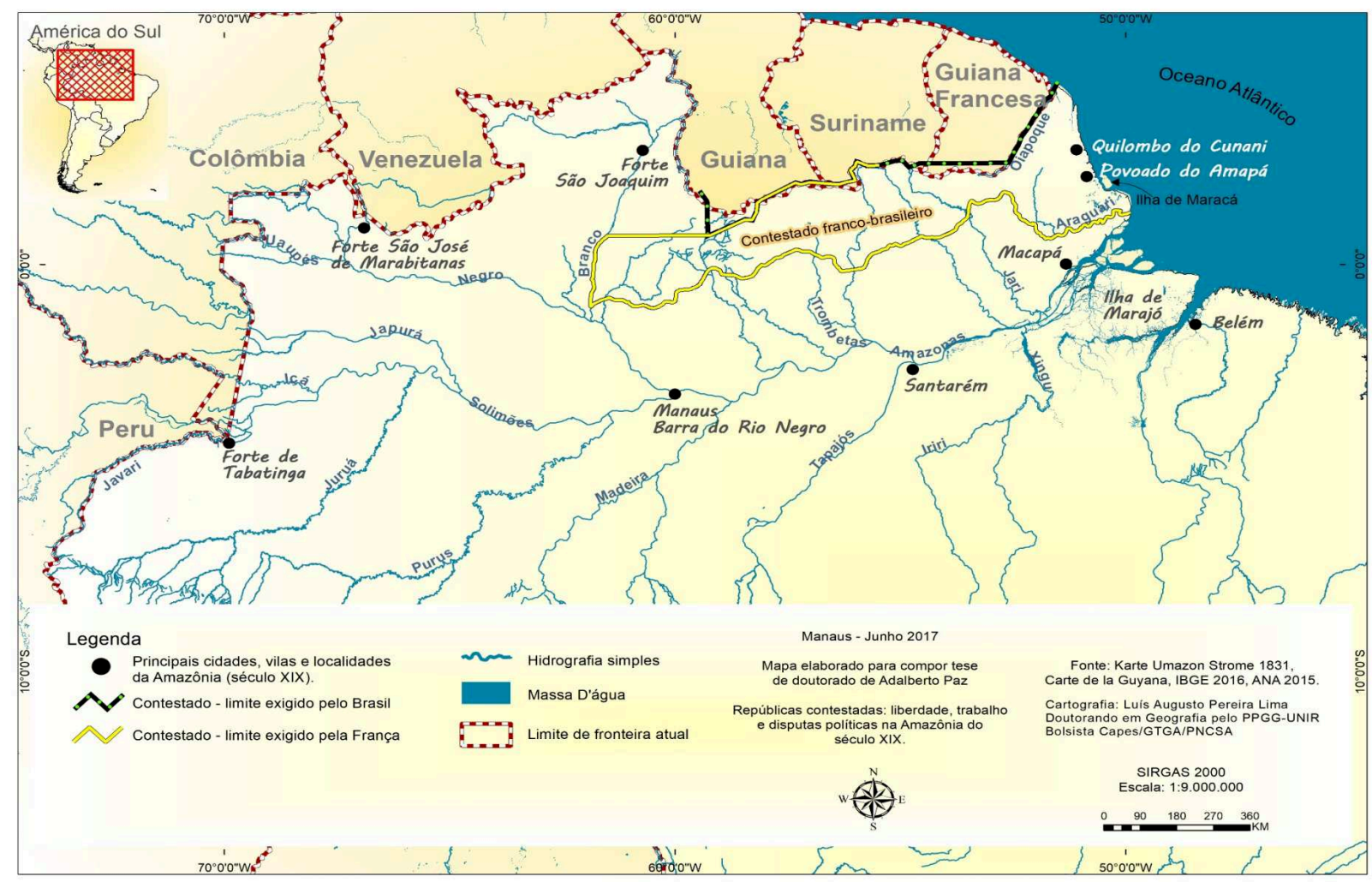

e nas vilas de Macapá e Mazagão, situadas na foz do rio Amazonas, não se poderia dizer que a Amazônia havia se tornado um "celeiro agrícola". Na verdade, antes mesmo do final do século XVIII, a prioridade dos interesses estratégicos de proteção e fortificação da área entre a ilha de Marajó e a Linha do Equador, e os graves limites de precariedades infraestruturais, arruinaram os povoados nas proximidades da fortaleza de São José de Macapá, assolados pela miséria, fome e mortes. ${ }^{6}$

Subindo o rio Amazonas, em direção à Barra do Rio Negro, atual Manaus, e indo além, na direção da Venezuela, Colômbia, Peru e Bolívia, incluindo as áreas de mocambos, era possível encontrar plantações diversas, como tabaco, mandioca, café, além dos produtos anteriormente mencionados. Porém, os itens oriundos do extrativismo mantinham inconteste proeminência tanto na economia quanto na subsistência local, sem mencionar o comércio de manufaturas com aqueles países limítrofes. Na província do Amazonas, havia significativa variedade de produtos das mais diversas regiões dos rios Solimões, Branco, Negro, Japurá,

Camponeses, donos de engenho e escravos na região do Acará nos séculos XVIII e XIX. Papers do NAEA n. 153, out. 2000. Disponível em http://www.naea.ufpa.br/naea/novosite/paper/309. Acesso em: 12 jan. 2015. LIMA, Ana Renata do Rosário de. Revoltas camponesas no vale do Acará 1822-1840. Belém: Prefeitura Municipal de Belém, 2004. Para o rio Tocantins, ver ANGELO-MENEZES, Maria de Nazaré. O sistema agrário do vale do Tocantins colonial: agricultura para consumo e para exportação. Projeto História. São Paulo, n. 18, p. 237-259, maio 1999.

6 Sobre os projetos e fracassos coloniais nas vilas de Macapá e Mazagão no século XVIII, ver MARIN, Rosa Elizabeth Acevedo. Prosperidade e estagnação de Macapá colonial: as experiências dos colonos. In: Flávio dos Santos Gomes (org.). Nas terras do Cabo Norte: fronteiras, colonização e escravidão na Guiana brasileira. Belém: Editora Universitária/UFPA, 1999. FERREIRA, Eliana. Estado e administração colonial: a vila de Mazagão. In: MARIN, Rosa Elizabeth Acevedo (org.). A escrita da história paraense. Belém: NAEA/UFPA, 1998. 
Juruá, Tefé, Purus, Madeira e outros, principalmente salsaparrilha, borracha, castanhas, copaíba, tartarugas, ovos e derivados dos três últimos, como óleos e manteiga. No mercado interno, também eram negociados e consumidos amplamente a farinha de mandioca, a cachaça, o pirarucu e outros peixes secos.

Contudo, o segundo objetivo determinante no qual as políticas pombalinas foram bastante malsucedidas, considerando aquilo que pretendiam e o que puderam realizar, diz respeito à constituição de uma sociedade amazônica plenamente assentada na escravidão negra africana, isto é, onde em todos os lugares os escravos negros fossem "as mãos e os pés" dos senhores, conforme a definição clássica de Antonil. ${ }^{7} \mathrm{O}$ cumprimento dessa meta, à primeira vista estritamente econômica, de fato representava uma encruzilhada para a qual convergiam várias outras expectativas do planejamento português para a Amazônia. Ela seria, ao mesmo tempo, a contrapartida e a condição sine qua non para a liberdade dos índios, e um dos pilares fundamentais para a afirmação da monocultura exportadora na região. ${ }^{8}$

Em relação ao tráfico de escravos africanos para o Grão-Pará e Maranhão, desde 1754 o governador Francisco Xavier de Mendonça Furtado acreditava que a solução ideal para essa questão seria a criação de uma empresa monopolista dedicada ao fornecimento de trabalhadores negros escravizados para a Amazônia. Assim, de modo articulado, tomaram-se as providências para a reestruturação dos mundos do trabalho amazônico no setecentos. No dia 6 de junho de 1755, foi assinada a lei que restituiria aos índios "a liberdade das suas pessoas, bens e comércio". ${ }^{9} \mathrm{E}$ no dia seguinte, 7 de junho, foram emitidos os alvarás de retirada do poder temporal dos religiosos sobre as missões e de criação do empreendimento planejado por Mendonça Furtado, ou seja, a Companhia Geral de Comércio do Grão-Pará e Maranhão.

A incorporação dos índios como súditos do rei português também era parte importante da estratégia metropolitana de consolidação da sua posse sobre territórios litigiosos com outras potências europeias, na América do Sul. Apesar disso, os entraves vivenciados pelo governador Mendonça Furtado diante das resistências dos colonos e missionários, quanto às proibições de acesso aos nativos, fizeram-no pensar em alternativas que pudessem conciliar os interesses políticos, econômicos e diplomáticos de Portugal com as demandas imediatas por mão de obra dos moradores do Grão-Pará e Maranhão.

Assim, após uma série de observações, experiências e ensaios administrativos peculiares na colônia, Mendonça Furtado reuniu um conjunto de propostas que se materializaram em um

7 ANTONIL, André João. Cultura e opulência do Brasil. Rio de Janeiro: Typographia Imp. e Const. de J. Villeneuve e C. ${ }^{a}, 1837$, p. 31.

8 Sobre o debate, entre as autoridades portuguesas, em torno da liberdade dos índios e o tráfico de africanos para a Amazônia, ver FARAGE, Nádia. As muralhas dos sertões: a colonização e os povos indígenas do rio Branco. Rio de Janeiro: Paz e Terra: ANPOCS, 1991, p. 36-44.

9 Lei de 6 de junho de 1755 para se restituir aos índios do Pará e Maranhão a liberdade de suas pessoas e bens. Cf. SILVA, Antonio Delgado da. Collecção da legislação portuguesa desde a última compilação das Ordenações. Legislação de 1750 a 1762. Lisboa: Typografia Maigrense, 1830, p. 369-376. Esta lei só entrou em vigor no estado do Grão-Pará e Maranhão em 1757. Reproduções fac-símiles das principais legislações indigenistas relacionadas à Amazônia se encontram em: MOREIRA NETO, Carlos de Araújo. Índios da Amazônia: de maioria a minoria (1750-1850). Petrópolis: Vozes, 1988, p. 152-206. 
documento composto de 95 parágrafos: o "Directorio que se deve observar nas Povoações dos Índios do Pará e Maranhão em quanto Sua Magestade não mandar o contrário", verdadeiro manual civilizatório, no qual eram reiteradas as ambições assimilacionistas de "diluição" do elemento indígena na sociedade colonial. Entre outras medidas, constavam o incentivo ao casamento entre brancos e índios e a extinção nestes de tudo o que fosse considerado de origem silvícola, impondo o uso de roupas "decorosas" e a adoção de nomes e do idioma português. ${ }^{10}$

Se não havia absoluta originalidade na ênfase dada à incorporação das populações autóctones ao projeto colonial, ${ }^{11}$ no tocante às relações de trabalho e formas de produção, o Diretório criava um precedente legal propositadamente ambíguo, como resposta às pressões econômicas e sociais da colônia. Essa ambiguidade se expressava através da garantia de que os colonos continuariam dispondo da mão de obra nativa, mesmo que teoricamente limitados por condições específicas. Em outras palavras, estava abolida qualquer exceção usada para legitimar o cativeiro indígena, mas isso não tornava estes completamente livres, uma vez que o Diretório fora concebido como "um instrumento que, contrariando as leis formuladas em Portugal, fundava uma regulação da liberdade concedida aos índios". ${ }^{12}$

Nesse contexto, o Diretório pretendia integrar o índio de forma menos submissa à sociedade colonial brasileira, reforçando as proibições quanto à escravização indígena, incentivando casamentos destes com os brancos, e até mesmo outorgando títulos honoríficos e autoridade política nos casos devidos. Na prática, porém, o Diretório almejava especialmente - embora não exclusivamente - pôr fim às constantes reclamações dos colonos quanto à escassez de braços para os empreendimentos, liberando a mão de obra que estava retida nas missões, sob a guarda espiritual e temporal das ordens religiosas. Por isso, não obstante tenha regulamentado a liberdade dos índios, enquanto vassalos do rei de Portugal, o Diretório também os tornou "trabalhadores disponíveis" através da organização de "Corporações", por meio das quais eram arregimentados e alocados compulsoriamente em serviços particulares ou em obras públicas, muitas vezes em áreas distantes de seus locais de origem. ${ }^{13}$

Além disso, as reformas pombalinas propunham uma "divisão étnica do trabalho", na qual os indígenas seriam empregados em atividades tais como os chamados "negócios das canoas", caça, coleta, pesca, e especificamente as mulheres eram ocupadas nas colheitas,

10 Mauro Cezar Coelho argumenta que o Diretório dos Índios foi uma legislação criada a partir dos embates entre os projetos metropolitanos pombalinos e as resistências à sua efetivação no Grão-Pará e Maranhão. Segundo o autor, isso atribui ao Diretório um caráter eminentemente colonial, uma vez que essa legislação não estava prevista antes da chegada de Francisco Xavier de Mendonça Furtado à Amazônia. Cf. COELHO, op. cit., p. 132-173.

11 Para uma análise sobre as regularidades e diferenças entre as várias legislações indigenistas na América portuguesa, ver PERRONE-MOISÉS, Beatriz. Índios livres e índios escravos: os princípios da legislação indigenista do período colonial (séculos XVI a XVIII). In: CUNHA, Manuela Carneiro da. História dos índios no Brasil. São Paulo: Companhia das Letras: Secretaria Municipal de Cultura: FAPESP, 1992. Ver também FARAGE, op. cit., p. 26-53.

12 COELHO, op. cit., p. 169.

13 BRITO, Cecília Maria Chaves. Índios das "corporações": trabalho compulsório no Grão-Pará no século XVIII. In: MARIN, Rosa Acevedo (org.). A escrita da história paraense. Belém: UFPA/NAEA, 1998, p. 125. 
serviços domésticos e no artesanato, acrescentando "o honrado exercício de cultivarem suas terras". ${ }^{14}$ Os negros escravizados, por sua vez, seriam a principal força de trabalho nas plantations de arroz, cana-de-açúcar, algodão e nas obras públicas. Ressalte-se, porém, não ser incomum que nativos e africanos dividissem os mesmos espaços de trabalho. No entanto, para que tudo isso se efetivasse era necessário que a escravidão negra se firmasse na base produtiva, separando e instituindo discriminações entre escravos e índios, sedimentando hierarquias também na base social.

Todavia, a Companhia do Grão-Pará e Maranhão não conseguiu cumprir à risca os seus objetivos. Os indígenas, portanto, continuavam sendo a principal mão de obra disponível na Amazônia, e todos os abusos relacionados a essa condição, ao invés de terem sido gradativamente extirpados - após a lei de liberdade de 1755, as regulações do Diretório e os incentivos ao tráfico de africanos -, acabaram se avolumando desenfreadamente. Assim, em 1797, o governador Francisco Coutinho elaborou um "Plano para a civilização dos índios do Pará", no qual culpava a ganância e a corrupção dos diretores de aldeamento pelo fracasso dos objetivos assimilacionistas que o Diretório tinha planejado para os nativos súditos de Sua Majestade. ${ }^{15}$ Nesse plano, Coutinho propunha à metrópole novos mecanismos de incorporação dos índios à sociedade colonial, reiterando a liberdade e a igualdade deles perante os demais vassalos, mas cobrando em troca diversas obrigações. ${ }^{16}$

As propostas do governador Coutinho se transformaram na Carta Régia de $1798,{ }^{17}$ documento mais conhecido por ter oficialmente extinguido o Diretório, embora também seja notabilizado pela criação de medidas que visavam acelerar a conversão dos índios em colonos, organizando-os em posições específicas no mundo do trabalho e na hierarquia militar da época. Essa associação entre trabalho e militarismo, aliás, é explicitada desde o início da Carta, ao determinar que todos os índios que viviam nas vilas, cidades e aldeias coloniais deviam ser alistados em "Corpos de Milícias". A partir destes, alguns seriam destacados para "Corpos Efetivos de Índios" - trabalhadores a serem preferencialmente engajados no Real Serviço -, outros para trabalhos "ajustados" com arrematantes de contratos públicos e demais particulares, e, por fim, certo número seria destinado a uma "Companhia de Pescadores". ${ }^{18}$

$14 \S 17$ do Directorio que se deve observar nas Povoaçoens dos Indios do Pará e Maranhaõ em quanto Sua Magestade naõ mandar o contrario. Disponível em http://bd.camara.gov.br/bd/handle/bdcamara/1929. Acesso em: 8 mar. 2016.

15 Arquivo Nacional do Rio de Janeiro. Plano para a civilização dos índios do Pará. 2 de agosto de 1797. Códice 101, v. 2, folhas $54-82$.

16 Algumas das principais propostas do plano eram justamente quanto ao uso da mão de obra indígena. Sobre isso, ver MACLACHLAN, Colin M. The Indian labor structure in the Portuguese Amazon, 1700-1800. In: ALDEN, Dauril (ed.). Colonial Roots of Modern Brazil: papers of the Newberry Library Conference. Berkeley; Los Angeles; London: University of California Press, 1973, p. 223-225.

17 Para uma análise sobre a Carta Régia de 1798, no contexto das políticas indigenistas portuguesas na Amazônia, ver SAMPAIO, Patrícia Melo. Administração colonial e legislação indigenista na Amazônia portuguesa. In: PRIORE, Mary Del; GOMES, Flávio. Os senhores dos rios. Rio de Janeiro: Elsevier, 2003, p. 123-139. MOREIRA NETO, op. cit. ALMEIDA, Rita Heloísa de. A Carta Régia de 12 de maio de 1798 e outros documentos sobre índios no códice 807. Revista do Instituto Histórico e Geográfico Brasileiro. Rio de Janeiro, a. 163, n. 416, p. 176-180, jul./set. 2002.

18 Carta Régia ao Capitão-General do Pará acerca da emancipação e civilisação dos índios; e resposta dele acerca de sua execução [doravante Carta Régia de 1798], 12 de maio de 1798. Revista do Instituto Histórico 
Contudo, é importante ressaltar que a Carta trazia uma inovação fundamentalmente crítica, somada aos objetivos e metas tradicionais das políticas indigenistas anteriores, manifestada nos mecanismos de compulsoriedade para toda a população livre "de cor", ou seja, negros, mamelucos e cafuzos.

Os Corpos de Milícias eram tropas auxiliares de segunda linha, não remuneradas, formadas por homens livres e válidos das classes mais baixas da sociedade, com idades entre 18 e 60 anos. Em geral, desde o século XVI, o primeiro alistamento era feito por unidades chamadas Ordenanças, cujos capitães-mores, sargentos e demais oficiais eram eleitos pelas Câmaras Municipais. Daquele arrolamento inicial, eram retirados os homens para as Milícias e as tropas de primeira linha (regulares e pagas), respeitando as exceções de recrutamento, principalmente para as últimas. ${ }^{19}$ Assim, ao exigir que os índios ingressassem diretamente em Milícias, o texto da Carta Régia criava margem para ambiguidades e conflitos não apenas burocráticos, mas nas relações de poder entre civis e militares, justamente porque Ordenanças, tropas auxiliares e regulares tinham a prerrogativa de controlar, classificar e organizar todos os moradores nas vilas e cidades. ${ }^{20}$

A partir da reforma militar portuguesa conduzida por Frederico de Schaumburg-Lippe, o conde de Lippe, em 1763, e implantada no Grão-Pará a partir de $1773,{ }^{21}$ ampliou-se a presença e os papéis desempenhados pelas Milícias e Ordenanças na vida social da colônia. Desde 1766, a Coroa já havia determinado que no Brasil fossem alistados todos os moradores livres, incluindo "nobres, brancos, mestiços, pretos, ingênuos, e libertos". ${ }^{22} \mathrm{Na}$ Amazônia, as medidas do conde de Lippe reforçavam a importância do amplo recrutamento, disciplinarização e treinamento militar básico voltado preferencialmente para a segurança interna, o que incluía a perseguição aos desertores e escravos fugidos. Do mesmo modo, a Carta Régia de 1798 enfatizava que as Milícias poderiam ser convocadas a qualquer momento para ajudar no enfrentamento a ameaças externas, principalmente nas fronteiras. ${ }^{23}$

Embora não haja dúvida sobre a absoluta ênfase dada por essa legislação às obrigações de trabalho e serviços militares que deveriam ser prestados, agora não somente por índios, mas também por mestiços, negros livres e libertos, já nas primeiras décadas do século XIX,

e Geographico Brazileiro [RIHGB]. Rio de Janeiro, tomo XX, p. 433-445, 1857. Será utilizada esta publicação da lei, que é a mesma reproduzida em MOREIRA NETO, op. cit., p. 220-247. Embora a Coroa portuguesa tenha emitido outras cartas régias no dia 12 de maio de 1798, a "Carta Régia ao Capitão-General do Pará acerca da emancipação e civilisação dos índios" é a única analisada neste artigo.

19 NOGUEIRA, Shirley Maria Silva. "A soldadesca desenfreada": politização militar no Grão-Pará na Era da Independência (1790-1850). Tese (doutorado em História) - Faculdade de Filosofia e Ciências Humanas, Universidade Federal da Bahia, Salvador, 2009, p. 107.

20 PRADO JÚNIOR, Caio. Formação do Brasil contemporâneo: colônia. 12ª ed. São Paulo: Brasiliense, 1972, p. 314; 324-328.

21 NOGUEIRA, op. cit., p. 100.

22 MELLO, Christiane Figueiredo Pagano. Forças militares no Brasil Colonial: Corpos de Auxiliares e Ordenanças na segunda metade do século XVIII. Rio de Janeiro: E-Papers, 2009, p. 143.

23 Carta Régia de 1798, RIHGB, p. 438. Importante notar que a expansão do sistema de recrutamento universal a partir do final do setecentos, em vários países e colônias, chamou a atenção dos governantes para os riscos de armar e treinar exércitos formados pelos socialmente excluídos considerados "politicamente instáveis". Cf. LUCASSEN, Jan; ZÜRCHER, Erik Jan. Conscription as military labour: the historical context. International Review of Social History, v. 43, issue 3, p. 413, dec. 1998. 
as autoridades paraenses divergiriam quanto ao caráter e ao enquadramento daqueles Corpos. Principalmente acerca de quem tinha voz de comando sobre os trabalhadores e milicianos conscritos. ${ }^{24}$ Isso porque, entre outras coisas, a Carta Régia delegava poderes a autoridades civis (Câmara e juízes) e a oficiais militares, mas também incentivava contatos e acertos diretos entre particulares, arrematadores de contratos e índios, sem intermediações ou autorizações prévias.

No cerne dessas disputas, havia uma peculiar e decisiva ambiguidade situada no cruzamento entre o processo de militarização da Colônia e as questões sobre a mão de obra livre e escrava no Grão-Pará. Tratava-se do dualismo criado pelas obrigações atribuídas pela Carta Régia aos índios e homens livres "de cor", na medida em que todos os alistados nos Corpos de Milícias - ou seja, toda a população masculina e economicamente ativa das vilas e cidades - passaram a constituir uma reserva pública de trabalhadores compulsórios, submetidos à mesma disciplina, hierarquia e supervisão usadas na organização dos contingentes militares.

Rompendo e embaralhando intencionalmente os limites entre trabalho livre e compulsório, o documento expressava a ambição de que nenhum homem pobre livre ou liberto, com condições físicas para prestar serviços e realizar trabalhos, pudesse escapar ao controle do Estado ou ficasse "sem ocupação". Dessa forma, logo após mencionar a formação das Milícias, a Carta Régia ordenava a criação do Corpo Efetivo de Índios, seguindo o modelo da Companhia de Pedestres de Mato Grosso e Goiás, "preferindo, porém, os pretos forros e mestiços enquanto os houver". ${ }^{25}$

A Companhia de Pedestres de Mato Grosso, mencionada como referência para a organização dos Corpos de Efetivos no Grão-Pará, existia desde 1755. Integrava, naquela Capitania, as forças militares pagas, e tinha como principal característica ser composta "exclusivamente de homens de cor e mestiços livres". ${ }^{26}$ Desde a sua criação, tivera grande importância como principal força de trabalho militar em diferentes épocas. Juntamente com as companhias de Aventureiros, Caçadores e Henriques, os pedestres mato-grossenses eram a maioria dos empregados nas "guarnições, bandeiras, expedições, correios e outras atividades importantes do Real Serviço". ${ }^{27}$ No Arsenal de Marinha, estariam presentes em diversos ofícios especializados e na extração de madeiras para a instituição, sendo possível encontrar pedestres até mesmo em trabalhos de lavoura. ${ }^{28}$ É preciso reconhecer, no entanto, que no

24 A respeito de tais divergências, ver SAMPAIO, 2011, op. cit., p. 236, 268, 291-295. MACHADO, André Roberto de A. O fiel da balança: o papel do Parlamento brasileiro nos desdobramentos do golpe de 1831 no Grão-Pará. Revista de História, São Paulo, n. 164, p. 195-241, jan./jun. 2011.

25 Carta Régia de 1798, RIHGB, p. 434.

26 CARVALHO, Francismar Alex Lopes de. "Com despesas próprias a bem do Real Serviço": funcionários, colonos e a defesa da fronteira no extremo oeste da América portuguesa, c.1750-1800. História. Franca, v. 33, n. 1, p. 174, jan./jun. 2014.

27 Ibidem.

28 MELLO, Saulo Álvaro. O Arsenal da Marinha em Mato Grosso: projeto político de defesa nacional e de disciplinarização do trabalho - Do planalto à planície pantaneira (1719-1873). Dissertação (Mestrado em História) - Faculdade de Ciências Humanas, Universidade Federal da Grande Dourados, Dourados, 2009, p. 145-146. 
Pará a Companhia de Pedestres e o Corpo Efetivo de Índios não se confundiam. De acordo com Antônio Baena, um importante intelectual e militar do início do século XIX, os pedestres paraenses seriam ocupados principalmente no "serviço de Polícia e diligências do Arsenal de Marinha”, ${ }^{29}$ enquanto, segundo a Carta Régia, os Corpos Efetivos seriam destinados a todos os trabalhos do Real Serviço.

Dessa maneira, segundo a Carta Régia, todos os índios, pretos forros e mestiços das vilas e cidades deveriam realizar trabalhos nas Milícias, a particulares e no Real Serviço. Este último era a principal função do Corpo Efetivo de Índios, que, apesar do nome, poderia ser multiétnico, contanto que fosse constituído por indivíduos "robustos e capazes de suportar o trabalho". ${ }^{30}$ Uma quantidade específica de índios podia ser arregimentada pelos juízes, a pedido dos arrematantes de contratos que não tivessem conseguido trabalhadores por conta própria. E, por fim, os particulares tinham o direito de dispor do trabalho de todos os nativos que conseguissem "tirar dos matos", assumindo apenas o compromisso de educá-los e instruí-los. ${ }^{31}$

Para que não houvesse conflitos na distribuição dessa mão de obra, a Carta definia prioridades. Os recrutamentos deveriam evitar prejuízos à "condução de madeiras e outros serviços em que utilmente se empregam os índios". Feita essa primeira exceção, determinou-se que o Corpo Efetivo do Real Serviço poderia contar com homens das Milícias para cumprir suas tarefas. Em compensação, os índios - notadamente os remeiros - a serviço dos arrematantes de contratos não podiam ser chamados para nenhum serviço público e nem para trabalhos nas Milícias. Essa condição, porém, era reservada a um número limitado de nativos, decidido pela Junta da Fazenda ou pelas Câmaras. ${ }^{32}$

Dessa forma, combinando critérios socioeconômicos - como tipo de propriedade, renda e forma de trabalho - e designativos étnico-culturais, conforme previsto na Carta Régia, tornava-se inquestionável o uso forçado da mão de obra daqueles submetidos a essas qualificações. Especificamente quanto aos índios, a ideia principal era punir "a inclinação natural de alguns deles ao ócio e inação", mas também demonstrar "justiça" àqueles que se dedicassem a fazer estabelecimento próprio. Nesse caso, seriam "particularmente isentos de todo o trabalho pessoal, logo que a importância dos dízimos que pagarem dos frutos que cultivarem exceda o jornal que poderiam ganhar". ${ }^{33}$

$\mathrm{Na}$ esteira dos projetos de reordenamento das complexidades sociais, econômicas e culturais da América portuguesa, a Carta Régia de 1798 sem dúvida aprofundou diversas

29 BAENA, Antônio Ladislau Monteiro. Compêndio das eras da Província do Pará. [1838] 2a ed. Belém: Universidade Federal do Pará, 1969, p. 240. BAENA, Antônio Ladislau Monteiro. Ensaio corográfico sobre a província do Pará. [1839] Brasília: Senado Federal, 2004, p. 127, 146.

30 Carta Régia de 1798, RIHGB, p. 434.

31 Os índios trazidos por particulares eram batizados e recebiam o status jurídico de órfãos. No termo de ajuste dessa tutela, deveria constar o número de anos de trabalho aos quais o particular tinha direito, como forma de indenização por eventuais gastos com esses descimentos. Ibidem, p. 442. Ver também FARAGE; CUNHA, op. cit., p. 108-110.

32 Ibidem, p. 436.

33 Carta Régia de 1798, RIHGB, p. 439. 
vulnerabilidades, distorções e ambiguidades referentes à liberdade dos índios. Mas não apenas isso. Em conjunto com instruções complementares emitidas pelo governador Francisco Coutinho ao longo de 1799 , as quais estenderam os alistamentos e recrutamentos à população pobre de modo geral, tais medidas consolidaram na Amazônia as bases modernas da ampla coação ao trabalho, para fins públicos ou particulares. A montagem dessa estrutura atendia a interesses militares e de disputas territoriais da Coroa portuguesa, ${ }^{34}$ mas também significava a criação de mecanismos de arregimentação e agrupamento contínuo de força de trabalho, em pontos estratégicos, do Alto ao Baixo Amazonas. Assim, quando o século XIX se iniciou, a região havia se tornado um lugar onde todo trabalho livre não autorizado poderia ser oficialmente recriminado, punido e apresado.

\section{Nem escravo, nem tão livre: o trabalho das milícias aos Corpos de Trabalhadores}

Os natURAlistas bávaros Johann Baptist von Spix e Carl von Martius estiveram na Amazônia entre 1819 e 1820, e realizaram uma viagem de cerca de oito meses, indo de Belém à fronteira com a atual Colômbia. ${ }^{35}$ Conheceram a região, portanto, num período imediatamente anterior a uma fase bastante turbulenta da história amazônida, que se iniciou com o chamado "Vintismo", em abril de 1821,36 e teve seu auge com a dramática irrupção da Cabanagem e a esmagadora repressão ao movimento, entre 1835 e $1840 .{ }^{37}$ No percurso de um extremo ao

34 Cf. BASTOS, Carlos Augusto de Castro. No limiar dos Impérios: projetos, circulações e experiências na fronteira entre a Capitania do Rio Negro e a Província de Maynas (c. 1780 - c. 1820). Tese (doutorado em História) - Faculdade de Filosofia, Letras e Ciências Humanas, Universidade de São Paulo, São Paulo, 2013.

35 As obras sobre a viagem completa realizada ao Brasil foram publicadas em três volumes, entre 1823 e 1831. Cf. LISBOA, Karen Macknow. A Nova Atlântida de Spix e Martius: natureza e civilização na Viagem pelo Brasil (1817-1820). São Paulo: Hucitec: FAPESP, 1997.

36 Sobre o Vintismo no Pará, ver COELHO, Geraldo Mártires. Anarquistas, demagogos e dissidentes: a imprensa liberal no Pará de 1822. Belém: Cejup, 1993.

37 A Cabanagem foi uma das mais importantes revoltas do período regencial. Ocorreu na província do Grão-Pará entre 1835 e 1840, e caracterizou-se pela intensa participação de índios, negros escravizados e demais segmentos pobres livres e libertos da Amazônia. Sobre esse e outros episódios sociais e políticos do início do século XIX, ver RAIOL, Domingos Antônio. Motins políticos ou história dos principais acontecimentos políticos da província do Pará desde o ano de 1821 até 1835. [1865-1890, 5 v.] 2a ed. Belém: Editora da UFPA, 1970, 3 v. No início do século XX, houve um renovado interesse pela Cabanagem, com autores ligados ao Instituto Histórico e Geográfico do Pará, ver HURLEY, Henrique Jorge. A Cabanagem. Belém: Livraria Clássica, 1936. Idem. Traços cabanos. Revista do IHGP, v. 10, 1936. CRUZ, Ernesto. Nos bastidores da Cabanagem. Belém: Oficina Gráfica da Revista de Veterinária, 1942. A partir dos anos 1980, foram realizadas novas interpretações e importantes balanços historiográficos sobre o tema, em forma de livros, dissertações e teses acadêmicas; ver CHIAVENATO, Julio José. Cabanagem: o povo no poder. São Paulo: Brasiliense, 1984. ROCQUE, Carlos. Cabanagem: epopeia de um povo. Belém: Imprensa Oficial, 1984, 2 v. DI PAOLO, Pasquale. Cabanagem: a revolução popular na Amazônia. Belém: Cejup, 1985. SALLES, Vicente. Memorial da Cabanagem: esboço do pensamento político-revolucionário no Grão-Pará. Belém: Cejup, 1992. SILVEIRA, Ítala Bezerra da. Cabanagem: uma luta perdida. Belém: Secretaria do Estado da Cultura, 1994. PINHEIRO, Luís Balkar Sá Peixoto. Nos subterrâneos da revolta: trajetórias, lutas e tensões na Cabanagem. Tese (doutorado em História) - Pontifícia Universidade Católica, São Paulo, 1998. Idem. Visões da Cabanagem: uma revolta popular e suas representações na historiografia. Manaus: Valer, 2001. RICCI, Magda. Do sentido aos significados da Cabanagem: percursos historiográficos. Anais do Arquivo Público do Pará, v. 4, t. 1, Belém, 2001, p. 241-274. LIMA, op. cit. BARBOSA, Mário Médice Costa. O povo cabano no poder: memória, cultura e imprensa em Belém-PA (1982-2004). Dissertação (Mestrado em História) - Pontifícia Universidade Católica, São Paulo, 2004. HARRIS, Mark. Rebellion on the Amazon: the Cabanagem, race and popular culture in the north of Brazil, 1798-1840. New York: Cambridge University Press, 2010. Em 2002, o Arquivo Público do Pará e a Secretaria de Cultura do Pará publicaram um conjunto de documentos reunidos pelo 
outro do rio Amazonas, Spix e Martius observaram e interagiram com uma notável diversidade de sujeitos, nas margens dos rios, em vilas e aldeias. E reuniram informações que depois foram complementadas por pesquisa bibliográfica sobre a colonização do vale.

Segundo os naturalistas, o sistema de recrutamento estava plenamente ativo em toda a Amazônia, de maneira que "para todos esses fins, são requisitados, diversas vezes por ano, bandos inteiros de índios jovens, tirados dos aldeamentos do interior e da ilha de Marajó, e remetidos para cidade [de Belém], onde recebem diárias de três vinténs, além de casa e comida". Os indígenas eram encontrados nas pescarias, obras públicas, estaleiro e arsenal, além de serem carregadores, e principalmente remadores, o que exigia vigilância e paciência, pois eles sempre fugiam, "deixando barco e passageiros em apuros". ${ }^{38}$ Este último aspecto era particularmente sensível, uma vez que, antes das transformações provocadas pela criação da Companhia de Navegação e Comércio do Amazonas, em 1852, o acesso e controle sobre os índios também era uma questão de mobilidade e transporte de pessoas e mercadorias. ${ }^{39}$

Após a estada em Barra do Rio Negro, Spix e Martius ressaltaram o quanto o recrutamento para as tropas de linha e milícias atendia a diversas finalidades. Segundo os autores, ao lado das obrigações de "policiamento e vigilância dos edifícios públicos", realizadas na vila, e de serviços nos fortes de Tabatinga, São José de Marabitanas e São Joaquim, os praças tinham que realizar tarefas que garantiam o funcionamento do comércio e demais atividades econômicas. Dentre estas, estavam as "patrulhas contra índios hostis" e a supervisão dos lugares onde eram encontradas tartarugas. ${ }^{40}$ Também realizavam "expedições no intuito de trazer índios livres aos povoados", ou seja, descimentos, e acompanhavam os viajantes que iam ao interior em busca de "produtos naturais". Além disso, uma parte da guarnição trabalhava nas fazendas de gado do governo, localizadas no rio Branco, e todos os integrantes das tropas podiam ser requisitados e "pagos à parte" para serviços privados. ${ }^{41}$

O controle da força de trabalho não escrava na Amazônia continuaria sendo exercido através de vários mecanismos, em conjunto, por mais de uma década. No Pará, contudo, uma série de reformas realizadas nas tropas regulares e auxiliares durante o período regencial

antropólogo David Cleary; ver CLEARY, David. Cabanagem: documentos ingleses. Belém: Arquivo Público do Pará: SECULT/IOE, 2002.

38 SPIX, Johann B. von; MARTIUS, Carl Friedrich P. von. Viagem pelo Brasil: 1817-1820. Belo Horizonte: Itatiaia; São Paulo: Editora da Universidade de São Paulo, 1981, v. 3, p. 26-28.

39 Sobre a navegação no rio Amazonas no século XIX, ver BASTOS, Aureliano Cândido Tavares. 0 valle do Amazonas - Estudo sobre a livre navegação do Amazonas, estatística, producções, commercio, questões fiscaes do valle do Amazonas. Rio de Janeiro: B. L. Garnier Editor, 1866. GREGÓRIO, Vitor Marcos. Uma face de Jano: a navegação do rio Amazonas e a formação do Estado brasileiro (1835-1867). São Paulo: Annablume: FAPESP, 2012. MARIN, Rosa Elizabeth Acevedo. Civilização do rio, civilização da estrada: transportes na ocupação da Amazônia no século XIX e XX. Papers do NAEA n. 170, maio 2004. Disponível em http://www. naea.ufpa.br/naea/novosite/paper/326. Acesso em: 17 out. 2015.

40 A coleta de ovos de tartarugas, para a fabricação de óleos e manteiga, era uma das atividades mais importantes em toda a Amazônia, sendo a carne do animal também bastante consumida, sobretudo em locais onde havia pouca oferta de carne bovina (por isso, as tartarugas eram chamadas de "gado do rio"). Era comum existirem verdadeiros "currais" domésticos, onde os quelônios eram mantidos como criação particular. Nas matas e rios, procurava-se restringir o acesso aos animais, através da fiscalização de um "capitão da praia", nomeado pelo governador. SPIX; MARTIUS, op. cit., p. 162-167, 177.

41 Ibidem, p. 143. 
levou à dissolução dos Corpos de Milicianos Ligeiros - criados pela Carta Régia de 1789 -, no dia 22 de agosto de $1831 . .^{42}$ Esta e outras medidas visavam reduzir, drasticamente, os efetivos militares em todo o Brasil, como resposta às instabilidades suscitadas pela abdicação de D. Pedro I.

O tratamento dispensado aos Corpos de Milícias Ligeiras compunha o rol das várias discordâncias entre os liberais do partido "filantrópico" e os chamados "restauradores" ou caramurus. Tais disputas ganhariam novas proporções após a vacância do trono e a constituição da Regência, não obstante os ânimos partidários na província do Pará já estivessem muito acirrados, meses antes da abdicação do imperador. Durante a Cabanagem, contudo, não foram só as divergências entre os grupos privilegiados que se tornaram evidentes, mas, sobretudo, as diferenças entre estes e a população mais ampla.

Não obstante a heterogeneidade dos envolvidos na deflagração da Cabanagem, ${ }^{43}$ os altos custos humanos e materiais acabariam recaindo, de todas as maneiras possíveis, sobre a população "de cor". ${ }^{44}$ Primeiramente, através de prisões e execuções que resultaram na morte de dezenas de milhares por toda a Amazônia. Em seguida, por meio da reestruturação de mecanismos de ordenamento social e compulsão ao trabalho, voltados especificamente para as "classes baixas" de origem negra, indígena e mestiça.

Assim, quando Francisco José Soares de Andrea assumiu a presidência do Pará, em abril de 1836, não se limitou apenas ao enfrentamento e eliminação da resistência cabana na capital e no interior. Tratava-se, igualmente, de garantir a integridade territorial e política do Império na sua porção mais setentrional. Nesse sentido, a maneira mais imediata encontrada por Soares de Andrea para "pacificar" a Amazônia foi a sua militarização total, dividindo o Grão-Pará em nove comandos militares e subordinando cada comandante diretamente à presidência. ${ }^{45}$

Segundo esses ditames, o comandante militar era a autoridade máxima e "o único responsável pela segurança e conservação da ordem nos distritos do seu comando", não tendo "sujeição alguma a conselhos ou pareceres de outrem; nem a requisições populares". Entre as suas primeiras atribuições, estava a realização de um alistamento geral de todas as pessoas residentes no seu distrito e a efetivação de pelo menos três tipos de recrutamento. Inicialmente, de homens entre 15 e 50 anos, para a formação da "Guarda Policial" que substituiria a Guarda Nacional já dissolvida. Outros dois eram relacionados ao Exército, sendo

42 BRASIL. Collecção das Leis do Império do Brazil de 1831. Actos do Poder Legislativo de 1831. Rio de Janeiro: Typographia Nacional, parte I, 1875, p. 76.

43 A respeito da complexidade de fatores e de grupos sociais envolvidos na Cabanagem, ver PINHEIRO, 1998, op. cit., p. 149-192, 241-307. RICCI, Magda. Cabanagem, cidadania e identidade revolucionária: o problema do patriotismo na Amazônia entre 1835 e 1840. Tempo, Niterói, v. 11, n. 22, p. 5-30, 2007.

44 Sobre as questões raciais na Amazônia e sua importância nos eventos e interpretações da Cabanagem, ver CLEARY, David. "Lost altogether to the civilized world": race and the Cabanagem in northern Brazil, 1750 to 1850. Comparative Studies in Society and History, Cambridge, v. 40, issue 1, p. 109-135, jan. 1998.

45 Esposição do estado e andamento dos negócios da província do Pará no Acto da entrega que fez da prezidencia o Ex. ${ }^{\text {mo }}$ Marechal Francisco Jozé de Souza Soares d'Andrea, ao Ex. ${ }^{\text {mo }}$ doutor Bernardo de Souza Franco, no dia 8 de abril de 1839. Pará: Typographia de Santos, e menor, 1839. 
um para a formação de oficiais, e outro, "sem pressa nem violência, mas sucessivo", voltado preferencialmente aos "mancebos bem constituídos e de boa conduta". 46

Estabelecidas as regras do aparato de segurança e ordem, o presidente voltou-se para o mundo do trabalho, através da constituição dos chamados Corpos de Trabalhadores. Criados sob autorização da Lei Provincial N ${ }^{\circ}$ 2, de 25 de abril de 1838, esses corpos reuniam índios, mestiços e pretos (que não fossem escravos) sem propriedade ou ocupação constante. ${ }^{47}$ Em agosto do mesmo ano, a regulamentação da lei dizia quais trabalhos ou condições eram dignos e aceitáveis:

$1^{\circ}$ Todo o indivíduo que tiver ofício, ou estabelecimento seu, do qual subsista, e que além disto possa ainda vender, e efetivamente venda algum gênero, não será chamado a serviço algum público, ou particular a título de vadio [...].

$2^{\circ}$ Todos os que estiverem engajados, por contratos escritos, como fâmulos; ou para qualquer serviço duradouro, e que incontestavelmente estejam nele empregados, também não serão compelidos a outro algum trabalho [...].

$3^{\circ}$ Todos os mestres de ofícios, que estejam em efetivo trabalho, e todos os feitores ou administradores de fazendas, bem como os vaqueiros que sejam constantes em uma mesma fazenda [...].

$4^{\circ}$ Todos os patrões de canoas, ou barcos, que tenham mais de seis meses de serviço no mesmo barco; bem como os remeiros que tiverem o dito tempo de serviço no mesmo barco, ou em barco da mesma casa [...]. ${ }^{48}$

Antepondo-se a esses critérios socioeconômicos, porém, estavam as distinções raciais. Dessa forma, as Instruções para a Organização dos Corpos de Trabalhadores e Regulamento dos mesmos Corpos determinavam que os oficiais encarregados dos alistamentos nos distritos separassem "todos os homens brancos capazes de pegarem em armas", entre 15 e 50 anos, para serem destinados à Guarda Policial. Depois disso, poderia ser feito o mesmo com os "homens de cor" que tivessem algum estabelecimento que provesse de modo satisfatório a eles mesmos e suas famílias. Observadas tais exceções e preferências para outras instituições e cargos, só então era realizado o alistamento "de todos os homens de cor desde a idade de dez anos" nos distritos, os quais efetivamente formariam os Corpos de Trabalhadores. ${ }^{49}$ Dessa forma, ao lado do critério racial, eram considerados automaticamente

46 Ibidem, p.19-21. Sobre o papel da Guarda Policial e a reorganização do Exército no governo de Soares de Andrea e nos anos 1850, ver BASTOS, Carlos Augusto de Castro. Os braços da (des)ordem. Indisciplina militar na província do Grão-Pará (meados do século XIX). Dissertação (mestrado em História) - Instituto de Filosofia e Ciências Humanas, Universidade Federal Fluminense, Niterói, 2004, p. 40-70.

47 Lei N. ${ }^{\circ}$ 2, de 25 de abril de 1838. In: Collecção das Leis da Província do Gram-Pará. Belém: Typographia da Aurora Paraense, tomo I [1838], parte I, 1854, p. 3-5. Instituto Histórico e Geográfico Brasileiro (IHGB), PER $0.7 .1-19$. [doravante Lei N. ${ }^{\circ} 2$, de 25 de abril de 1838].

48 Regulamento dos Corpos de Trabalhadores. In: Esposição do estado e andamento dos negócios da província do Pará no Acto da entrega que fez da prezidencia o Ex mo Marechal Francisco Jozé de Souza Soares d'Andrea..., op. cit., p. 26.

49 Ibidem, p. 24. Em 24 de outubro de 1840, a lei original dos Corpos de Trabalhadores seria alterada pela Lei N. ${ }^{\circ}$ 84, por meio da qual ficou definida a idade mínima de 14 anos para o alistamento e autorizavam-se isenções aos oficiais, aprendizes de ofícios mecânicos, feitores de fazenda de agricultura e gado (reiterando o que já estava previsto no regulamento de 1838), e ao "varão único que tiver família a seu cargo". Cf. Lei N. 84, de 24 de outubro de 1840. In: Collecção das Leis da Província do Gram-Pará, Belém: Typographia da Aurora Paraense, tomo III [1840], parte I, 1854, p. 95, IHGB, PER 0.7.1-19. 
alistáveis os indivíduos que não comprovassem participação ativa na sociedade como sujeitos úteis, laboriosos e produtivos.

De modo explícito, portanto, os Corpos de Trabalhadores foram concebidos como parte dos mecanismos de um Estado militarizado, para conter e restringir as classes consideradas responsáveis pela "anarquia" e prejuízos ocorridos durante a Cabanagem. Não por acaso, essa interpretação foi enfatizada e consolidada por alguns dos estudiosos daquele movimento social, entre os séculos XIX e XX. ${ }^{50}$ Mais recentemente, outras análises buscaram destacar os vínculos do contexto amazônico oitocentista e da instituição criada por Soares de Andrea com as questões nacionais do período relacionadas a temas como a "transição do trabalho escravo para o trabalho livre", a construção do discurso de valorização do trabalho regular e moralmente edificante e a criação de estratégias oficiais de combate à "vadiagem". 51

Por outro lado, o que se pretende enfatizar é que os Corpos de Trabalhadores representam o auge de uma política oficial de arregimentação compulsória de trabalhadores, através de legislações e práticas criadas e aperfeiçoadas com essa finalidade a partir do Diretório, em meados do século XVIII. Desde então, a ideia de uma liberdade condicionada pelo trabalho e para o trabalho moldou os parâmetros de governos não apenas permissivos quanto a diferentes formas de escravidão - inclusive ilegais - e coações, mas efetivamente comprometidos com a garantia do fornecimento de mão de obra para empreendimentos públicos e particulares. Por isso, várias mudanças na sociedade refletiram-se também nas leis de compulsoriedade que foram estendidas a outros grupos, além dos indígenas.

Contudo, se a relação entre Francisco de Sousa Coutinho e o Diretório torna-se clara e direta, pelo próprio empenho do governador em extinguir e substituir aquela legislação indigenista, as referências e influências entre a Carta Régia de 1798 e os Corpos de Trabalhadores acabaram obscurecidas pelas múltiplas rupturas ocorridas no processo da Cabanagem e pelo furor persecutório de Soares de Andrea, em nome da pacificação do Grão-Pará. Mas é evidente que tanto Sousa Coutinho quanto Soares de Andrea não romperam completamente com os princípios básicos da compulsoriedade legal na Amazônia, tendo cada um a seu modo, aliás, contribuído para afirmá-la (ver Quadro 1). ${ }^{52}$

Corrobora essa afirmação, inclusive, o fato de que a lei dos Corpos de Trabalhadores de modo algum se apresentava enquanto instrumento de reformulação da política indigenista,

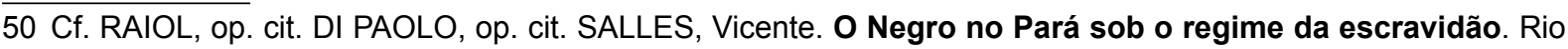
de Janeiro: Fundação Getúlio Vargas, 1971. Idem, 1992, op. cit. SILVEIRA, op. cit.

51 Cf. FULLER, Claudia Maria. Os Corpos de Trabalhadores: política de controle social no Grão-Pará. Revista Estudos Amazônicos. Belém, v. 3, n. 1, p. 93-115, 2008. BASTOS, 2004, op. cit., p. 29-40.

52 Vicente Salles e Carlos de Araújo Moreira Neto pontuam comparações entre as legislações indigenistas do século XVIII e a lei de 1838, quanto ao uso da força de trabalho de índios e pobres livres na Amazônia. Para o primeiro, o Diretório "inspirou" os Corpos de Trabalhadores, enquanto o segundo argumenta que estes "reintroduziram" o recrutamento nos moldes da Carta Régia de 1798. Cf. SALLES, 1992, op. cit., p. 61. MOREIRA NETO, op. cit., p. 97. Idem. Igreja e Cabanagem (1832-1849). In: HOORNAERT Eduardo (Org.). História da Igreja na Amazônia. Petrópolis: Vozes, 1992. 
tal como o fizera a Carta Régia de 1798 em relação ao Diretório. ${ }^{53}$ Entretanto, a drástica redução dos efetivos militares, logo no início da Regência, e particularmente a extinção das milícias de ligeiros, em 1831, haviam comprometido seriamente a legitimidade, e até certo ponto o funcionamento, do sistema de recrutamento estabelecido no final do século XVIII. Em um ofício de dezembro de 1837, ou seja, quatro meses antes de sancionar a Lei $N .^{\circ} 2$, Soares de Andrea demonstrava que conhecera bem o propósito desses corpos no Pará, mas os desdenhava pela sua indefinição na hierarquia militar. Para ele, as milícias de ligeiros, "sem serem corpos, propriamente de segunda linha", estavam igualmente submetidas ao comandante das armas, e "serviam sobretudo para conservar na obediência a uma classe muito numerosa de povo desta província". ${ }^{54}$ A "classe" referida no documento eram índios, mamelucos e cafuzos.

\section{Quadro 1. Esquema comparativo da organização do trabalho compulsório na} Amazônia entre os séculos XVIII e XIX.

\begin{tabular}{|c|c|c|c|c|c|c|}
\hline \multirow[b]{2}{*}{$\begin{array}{l}\text { Unidade } \\
\text { administrativa e } \\
\text { organização }\end{array}$} & \multirow{2}{*}{$\begin{array}{c}\text { Diretório - } 1757 \\
\begin{array}{c}\text { Corporações de } \\
\text { índios }\end{array}\end{array}$} & \multicolumn{4}{|c|}{ Carta Régia de 1798} & \multirow{2}{*}{$\begin{array}{c}\text { Corpos de } \\
\text { Trabalhadores - } 1838 \\
\text { Esquadra, Companhia e } \\
\text { Corpo de Trabalhadores }\end{array}$} \\
\hline & & $\begin{array}{l}\text { Milícias de } \\
\text { Ligeiros }\end{array}$ & $\begin{array}{c}\text { Corpo Efetivo de } \\
\text { Índios }\end{array}$ & $\begin{array}{l}\text { Arrematantes } \\
\text { de contratos } \\
\text { reais e demais } \\
\text { particulares }\end{array}$ & $\begin{array}{c}\text { Serviços de } \\
\text { pescaria }\end{array}$ & \\
\hline $\begin{array}{l}\text { Controle da mão } \\
\text { de obra }\end{array}$ & $\begin{array}{l}\text { Diretores, juízes, } \\
\text { Câmaras e } \\
\text { índios Principais }\end{array}$ & $\begin{array}{c}\text { Oficiais } \\
\text { comandantes } \\
\text { (índios Principais } \\
\text { e moradores } \\
\text { brancos) }\end{array}$ & \begin{tabular}{|} 
Cabos, sargentos, \\
capitães de \\
campo e de mato
\end{tabular} & $\begin{array}{c}\text { Câmaras, } \\
\text { ouvidores e juízes } \\
\text { de distrito }\end{array}$ & $\begin{array}{l}\text { Os pescadores } \\
\text { podiam se } \\
\text { autogerir ou ficar } \\
\text { sob "direção } \\
\text { alheia" }\end{array}$ & $\begin{array}{c}\text { Comandantes, } \\
\text { sargentos, fiscais e } \\
\text { cabos. Juízes de Paz } \\
\text { atestavam contratos } \\
\text { particulares autorizados } \\
\text { pelos Comandantes }\end{array}$ \\
\hline $\begin{array}{l}\text { Origem étnico- } \\
\text { racial e condição } \\
\text { social dos } \\
\text { trabalhadores }\end{array}$ & Indígenas & $\begin{array}{l}\text { Toda a população } \\
\text { pobre e livre, } \\
\text { incluindo os } \\
\text { brancos e índios }\end{array}$ & $\begin{array}{c}\text { Índios, } \\
\text { "preferindo, } \\
\text { porém, os pretos } \\
\text { forros e mestiços } \\
\text { enquanto os } \\
\text { houver" }\end{array}$ & $\begin{array}{l}\text { Índios "tapuios" } \\
\text { e índios recém- } \\
\text { descidos e } \\
\text { apresentados às } \\
\text { autoridades }\end{array}$ & Indígenas & $\begin{array}{l}\text { "Índios, mestiços e } \\
\text { pretos, que não forem } \\
\text { escravos" }\end{array}$ \\
\hline $\begin{array}{l}\text { Principais } \\
\text { ocupações }\end{array}$ & $\begin{array}{l}\text { Agricultura, } \\
\text { extrativismo, } \\
\text { "negócios das } \\
\text { canoas" }\end{array}$ & $\begin{array}{l}\text { Todo e qualquer } \\
\text { serviço a } \\
\text { que fossem } \\
\text { chamados, } \\
\text { incluindo defesa } \\
\text { militar da } \\
\text { Capitania }\end{array}$ & $\begin{array}{l}\text { Real Serviço, } \\
\text { principalmente } \\
\text { condução de } \\
\text { madeiras }\end{array}$ & $\begin{array}{c}\text { Navegação } \\
\text { fluvial, "roçados" } \\
\text { e extrativismo }\end{array}$ & $\begin{array}{l}\text { Exclusivamente } \\
\text { pescaria } \\
\text { (eram } \\
\text { dispensados } \\
\text { das milícias e do } \\
\text { Corpo Efetivo) }\end{array}$ & $\begin{array}{l}\text { Lavoura, comércio, } \\
\text { obras públicas } \\
\text { e tripulação de } \\
\text { embarcações }\end{array}$ \\
\hline
\end{tabular}

O presidente, assim, entendia a importância dos ligeiros no tocante ao controle social, mas se negava a reconhecê-los como "tropas". Em parte, essa visão pode ser creditada a sua perspectiva de formação de um exército profissional qualificado, constituído por homens com genuína "aptidão militar", e não somente por "desqualificados" avulsamente recrutados. Adicionalmente, existia a desconfiança que Soares de Andrea nutria pelos "muito numerosos"

53 Até porque, os interesses de Soares de Andrea não eram propriamente "indigenistas". Pouco tempo antes, porém, em dezembro de 1831, o major Antônio Baena havia apresentado um novo e completo regulamento direcionado aos índios do Pará. Cf. BAENA, Antônio Ladislau. Representação ao Concelho Geral da Província do Pará sobre a especial necessidade de um novo regulamento promotor da civilisação dos índios da mesma província. Annaes da Biblioteca e Archivo Público do Pará. Belém: Imprensa Oficial, 1902, tomo II, p. 241-292.

54 APEP, Fundo da Secretaria da Presidência da Província, Correspondência de Governo com a Corte, Códice 1065, Tribunais Superiores e Autoridades da Corte. Ofício de 20 de dezembro de 1837. 
homens "de cor" do Grão-Pará, e o seu "inconformismo" declarado com a "criação de corpos a quem se entregam armas, sem que sejam sujeitos a mais rigorosa disciplina". Por essa razão, dos quase dois mil homens reunidos em tropas naquele momento, mil e trezentos eram de outras províncias. ${ }^{55}$

Dessa forma, ao acompanharmos as decisões e os argumentos que antecedem e orientam a organização dos Corpos de Trabalhadores, notamos expressivas continuidades em relação a instituições anteriores que tinham as mesmas finalidades, ou seja, a arregimentação compulsória de indígenas, posteriormente acrescida de negros e mestiços.

Mas também ocorreram mudanças que remontam diretamente aos desígnios e às peculiaridades da militarização implantada por Soares de Andrea. Entre as mais importantes, nesse sentido, podemos destacar o claro esforço em separar a "dignidade" atribuída aos corpos militares da infâmia que recaía sobre os trabalhadores compulsórios. A coação ao trabalho que antes era justificada como contrapartida obrigatória de uma suposta igualdade entre os vassalos d'El Rey tornou-se finalmente apenas desonra e castigo, após a Lei N.$^{\circ} 2$, de 1838. O fardo adequado aos indolentes com "miseráveis" atributos raciais e sociais.

Outra característica da política de compulsoriedade criada durante a repressão à Cabanagem parecia caminhar no sentido de pôr fim a uma série de disputas entre as autoridades pelo domínio da população pobre livre e recrutável. Tratava-se da determinação expressa francamente pelo próprio Soares de Andrea, em seu relatório final de governo, de que "todos os Comandantes Militares são ao mesmo tempo os Comandantes das Guardas Policiais, e os Comandantes dos Corpos de Trabalhadores". ${ }^{56} \mathrm{Em}$ termos práticos, e conforme a lei, significava que os juízes de paz estavam completamente impedidos de arregimentar trabalhadores - mesmo nos casos previstos pela Carta Régia de 1798 -, devendo restringir-se a lavrar os contratos que fossem autorizados pelos comandantes, entre particulares e trabalhadores alistados nos corpos. ${ }^{57}$

Mais do que pender a balança definitivamente a favor dos comandantes militares, a lei de 1838 não deixava dúvida sobre a intenção de reabilitá-los social e politicamente. O que acabava sendo uma resposta - intencional ou não - às sucessivas medidas que, desde o início da década de 1830, objetivavam reduzir a influência, o poder, e consequentemente os abusos, daquelas autoridades sobre as populações civis. Desse modo, o Artigo $3^{\circ}$ da Lei dos Corpos de Trabalhadores determinava que seus comandantes e oficiais fossem os mesmos dos "antigos Corpos de Ligeiros", e, na falta destes, "os cidadãos mais idôneos"58 de cada distrito, os quais receberiam nomeações e patentes para exercer essa função.

55 Discurso com que o presidente da província do Pará fez a abertura da $1^{a}$ sessão da assemblea provincial no dia 2 de março de 1838. Pará: Typographia Restaurada de Santos, e Santos menor, Pará, 1838, p. 21.

56 Esposição do estado e andamento dos negócios da província do Pará no Acto da entrega que fez da prezidencia o Ex. ${ }^{\text {mo }}$ Marechal Francisco Jozé de Souza Soares d'Andrea..., op. cit., p. 6.

57 Cf. Lei N. ${ }^{\circ} 2$, de 25 de abril de 1838 , art. $4^{\circ}$.

58 Ibidem, art. $3^{\circ}$. 
Nesses moldes, a restituição de poderes aos oficiais dos extintos Corpos de Ligeiros ocorria por meio de uma "atualização" e releitura, feita por Soares de Andrea, acerca dos papéis atribuídos às duas principais instituições de trabalho compulsório presentes na Carta Régia de 1798, isto é, as Milícias e os Corpos Efetivos de índios. Sob os auspícios do marechal-presidente, o recrutamento para serviços públicos e particulares seria direcionado à população masculina civil e "de cor", administrada e supervisionada exclusivamente por militares em uma única instituição. Para isso, a estrutura definida pelas Instruções para a Organização dos Corpos de Trabalhadores era que:

\begin{abstract}
Em cada vila, ou Freguesia, se nomeará uma pessoa das de mais consideração, preferindo-se Oficiais Reformados, ou Oficiais das extintas Milícias, para Comandante de todas as Esquadras organizadas no distrito daquela vila ou Freguesia, com os quais se formará uma Companhia, que terá por título Companhia de Trabalhadores da Vila de ... ou da Freguesia de ... . Na mesma vila, ou Freguesia se nomeará um substituto do Comandante da Companhia, com a denominação de Sargento, e terá todas as atribuições do Comandante na sua falta, e as de Fiscal, por autorização do do [sic] Corpo [...]. Reunidas todas as Companhias das Vilas, e Freguesias de um Comando Militar formarão um Corpo, que terá por título: Corpo de Trabalhadores do Comando Militar de... O Comando Militar respectivo será o Comandante do Corpo de Trabalhadores [...]. Tanto o Fiscal como os Comandantes das Companhias serão considerados oficiais, podendo logo usar dos distintivos, aquele de Major, e estes de Capitães. ${ }^{59}$
\end{abstract}

Pouco mais de um ano após Soares de Andrea deixar o governo, uma portaria atestava que alguns juízes não haviam aceitado a condição protocolar à qual tinham sido reduzidos. Nela, eram censurados os magistrados que "alugavam" trabalhadores a terceiros, sem a necessária permissão dos comandantes. Para enfatizar a irregularidade dessa prática, o documento reafirmava que os trabalhadores eram "subordinados" unicamente aos comandantes, e por isso não estavam "à disposição dos juízes de paz". No ensejo, a portaria dizia que essas situações causavam "dissensões e divergências" entre as autoridades, o que era preciso evitar. ${ }^{60}$

Ao longo dos anos, haveria outras disputas em torno dos Corpos de Trabalhadores, envolvendo também proprietários, militares daquela instituição e o governo pelo controle da mão de obra. Da mesma forma, os próprios trabalhadores criavam estratégias para esquivar-se, principalmente, de serem recrutados para obras públicas. Nesse sentido, buscavam isenções previstas em lei, asseguravam arranjos pessoais por meio de contratos particulares, alistavam-se no Corpo Policial, perambulavam ou fugiam definitivamente. ${ }^{61}$ Assim como outros dispositivos legislatórios de compulsão ao trabalho na Amazônia, os Corpos de

59 Esposição do estado e andamento dos negócios da província do Pará no Acto da entrega que fez da prezidencia o Ex. mo Marechal Francisco Jozé de Souza Soares d'Andrea..., op. cit., p. 24-25.

60 Portaria de 25 de maio de 1840. In: Collecção das Leis da Província do Gram-Pará, Belém: Typographia da Aurora Paraense, tomo III [1840], parte II, 1854, p. 17-18, IHGB, PER 0.7.1-19.

61 Cf. FULLER, Claudia. "V. S. ${ }^{a}$ não manda em casa alheia": disputas em torno da implantação dos Corpos de Trabalhadores na Província do Pará, 1838-1844. Revista Estudos Amazônicos. Belém, v. 3, n. 2, p. 41-75, 2008. 
Trabalhadores estavam sujeitos a diferentes apropriações e oposições que interferiam na dinâmica do seu funcionamento.

A partir dos anos 1840, o discurso de recuperação econômica da Amazônia tornou-se imperativo na região. Contudo, existiam obstáculos importantes a tal anseio, relacionados aos enormes danos financeiros, populacionais e psicológicos dos anos de insurgência e repressão à Cabanagem, cujas marcas ainda se fariam visíveis por bastante tempo. Incluíam-se nesses aspectos os traumas e medos causados pelas violências e assassinatos generalizados, e, em decorrência disso, reduções e reconfigurações demográficas, migrações, fugas, aumento das ocupações nas áreas de fronteiras internacionais, e arranjos diversos entre autoridades, proprietários, comerciantes e as populações pobres livres e escravas. Por meio da análise dessas experiências, aproximamo-nos também das ações, limites e possibilidades presentes nesse complexo e emaranhado cenário.

\section{De "medida necessária e útil" a "servidão odiosa": o fim dos Corpos de Trabalhadores}

Como vimos, na Amazônia os recrutamentos para as forças militares e policiais coadunavam-se aos alistamentos para os Corpos de Trabalhadores, com o objetivo de que nenhum pobre livre ou liberto estivesse fora do alcance dos prepostos do Estado, quando fosse necessário e imediato dispor de praças ou mão de obra. No caso da instituição criada por Soares de Andrea, havia comandantes, capitães e sargentos espalhados por diversas vilas do interior, com autonomia administrativa, mas também integrando uma ampla rede de imobilização da força de trabalho.

Nesse sentido, a Lei N. ${ }^{\circ} 2$, de 25 de abril de 1838, limitava severamente a circulação dos indivíduos engajados nos Corpos de Trabalhadores, determinando que eles não poderiam sair ou transitar fora dos locais onde estavam alistados "sem guia de seus comandantes, que declare o lugar e fim a que se dirigem". Aqueles que não portassem esse documento seriam presos pelo juiz de pazonde fossem encontrados e remetidos aos "respectivos comandantes" ${ }^{62}$ O regulamento da instituição ordenava que "todos os homens de cor" que fossem reincidentes na prática de andar sem a guia deveriam ser presos e enviados ao governo "para [este] Ihes dar destino, quando a sua culpa não seja outra”. As opções previstas, então, seriam empregá-lo em uma "fábrica do governo" ou alugá-lo a um particular. Mas, "se apesar desta medida se esquivar ainda ao trabalho", a ordem era de que fosse remetido ao Arsenal de Marinha, "para ali trabalhar pela simples ração, e pelo tempo que se julgar preciso, segundo a sua conduta". ${ }^{63}$

62 Lei N. ${ }^{\circ} 2$, de 25 de abril de 1838 , art. $5^{\circ}$.

63 Regulamento dos Corpos de Trabalhadores. In: Esposição do estado e andamento dos negócios da província do Pará no Acto da entrega que fez da prezidencia o Ex mo Marechal Francisco Jozé de Souza Soares d'Andrea..., op. cit., p. 26-27. 
Entre as décadas de 1840 e 1850, uma das principais finalidades dos Corpos de Trabalhadores era o fornecimento de tripulantes para as embarcações que transitavam pela Amazônia, embora existissem outras formas de se conseguir homens para esse serviço. Nos arredores de Belém, os viajantes que transitavam pelos rios Tocantins, Guamá, Capim, Acará e na ilha do Marajó amiúde podiam contar com "remeiros" empregados dos proprietários das fazendas e engenhos localizados nessas regiões. Diversas vezes, eram equipes bastante heterogêneas, compostas por índios "tapuios", mestiços e negros escravizados, livres e libertos.

Em relação ao acesso à mão de obra indígena, o Decreto N. ${ }^{\circ} 426$, de 24 de julho de 1845, instituiu o "Regulamento acerca das Missões de catequese, e civilização dos Índios", determinando a criação de uma Diretoria Geral de Índios em cada província, sendo o diretor nomeado pelo imperador. A proposta era organizar aldeamentos conforme as possibilidades e conveniências locais, designando para administrá-los um Diretor de Aldeia ou Diretor Parcial, este nomeado pelos presidentes de província. ${ }^{64}$ Não demorou muito, contudo, para que os próprios presidentes se mostrassem céticos quanto aos resultados dessa política.

Um importante resumo dos obstáculos ao regulamento consta na fala do presidente do Pará, Jeronimo Francisco Coelho, à Assembleia Provincial paraense, em 1848. Segundo ele, não havia recursos para "manter tantas missões, e fundar tantos aldeamentos em todos os pontos, em que eles se fazem precisos". Isso porque, antes dever-se-ia atrair os índios com "mimos e presentes" (anzóis, contas de vidro, machados, facas e facões, tecidos, espelhos etc.), pagar um missionário para cada aldeamento, depois redistribuir roupas, ferramentas "e novos brindes". 65

Quanto às finalidades das missões, uma enorme dificuldade na visão do presidente seria incutir nos índios a tão almejada afeição pelo trabalho disciplinado, uma vez que eles seriam "habituados desde a infância a uma vida ambulante e a mais absoluta independência, [portanto] não abandonam de repente os seus hábitos naturais, para se sujeitarem à vida fixa e inamovível, a trabalhos regulares e diários". ${ }^{66}$

Jeronimo Coelho não poupou sequer os princípios administrativos do regulamento, condenando a legitimidade de que desfrutavam os diretores parciais, por meio das funções conferidas a eles através da lei, e a independência que arrogavam a si mesmos, sem dar informações "nem respostas dos ofícios que recebem". Na opinião do presidente, o regulamento atribuía poderes demais aos diretores, tornando-os tenentes-coronéis enquanto ocupassem

64 Cf. BRASIL. Collecção das Leis do Império do Brasil de 1845. Rio de Janeiro: Typographia Nacional, tomo VIII, parte II, 1846, p. 86-96. Para outras questões sobre o elemento indígena no século XIX, ver MONTEIRO, John. Tupis, tapuias e historiadores: estudos de história indígena e indigenismo. Tese (Livre Docência em Antropologia) - Instituto de Filosofia e Ciências Humanas, Universidade Estadual de Campinas, Campinas, 2001, p. 129-169.

65 Falla dirigida pelo exm. ${ }^{\circ}$ snr. Conselheiro Jeronimo Francisco Coelho, presidente da província do Gram-Pará, á Assembléa Legislativa Provincial na abertura da sessão ordinária da sexta legislatura no dia $1 .^{\circ}$ de outubro de 1848. Pará: Typographia de Santos \& Filhos, 1848, p. 101-102.

66 Ibidem, p. 102-103. 
o cargo, deixando-os livres para constranger aos índios com "aparato militar, inamovibilidade, sujeição e trabalho forçado". ${ }^{67}$

Não obstante, em lugares mais distantes da capital, como nos rios Xingu, Madeira, Tapajós e nos afluentes do rio Amazonas, Solimões e Negro, na porção ocidental da província, os tripulantes indígenas para as embarcações eram geralmente obtidos através de negociação com os chefes das tribos, os tuxauas. Sobre isso, é interessante ressaltar que, apesar de serem mencionados repetidamente como "tapuias" pelos viajantes, estes não deixaram de notar diferentes marcas físicas e adornos específicos, cultura material e religiosidade, idiossincrasias, alianças e rivalidades entre os índios das suas expedições. Dentre as muitas etnias citadas, estão os Juruna, Munduruku, Mura, Maués, Miranha, Uaupés e outros.

Até mesmo os Corpos de Trabalhadores podiam se valer da liderança dos tuxauas, para ter acesso à força de trabalho dos índios em determinadas regiões. Em um breve relato sobre a estrutura administrativa do Grão-Pará, o inglês William $\mathrm{H}$. Edwards afirma que, quando "certo número de homens são requeridos para navegar um barco, ou qualquer outro propósito", 68 o "capitão dos trabalhadores" enviava um requerimento ao tuxaua, e este deveria providenciar os índios solicitados, independentemente das suas ocupações particulares.

Entre os condicionantes que influenciavam a impressão geral da alegada "escassez de braços" na Amazônia oitocentista estava a possibilidade dos subalternos se utilizarem dos variados recursos naturais disponíveis, e das intrincadas relações sociais constituídas, para negar ou contornar o status quo baseado na dominação e exploração. Contra isso, na tentativa de evitar ou eliminar a realização dessas alternativas aos desfavorecidos, as elites econômicas e políticas historicamente reforçavam seus mecanismos de coação e compulsão generalizados. ${ }^{69}$ Considerando que o processo de privatização dos recursos, especialmente das terras, no Pará e no Amazonas, não seguiu os mesmos princípios das áreas de plantation, várias formas de imobilização e compulsoriedade se mantiveram em ambas as províncias por todo o século XIX.70

67 Ibidem, p. 103-104.

68 EDWARDS, William H. A voyage up the river amazon including a residence at Pará. New York: D. Appleton \& Company, 1847, p. 105.

69 Em sua obra clássica, Herman J. Nieboer afirma que a escravidão torna-se mais comum em lugares com recursos materiais "abertos", ou seja, ao alcance de todos ou da maioria. Inversamente, a escravidão tenderia a desaparecer onde os recursos estivessem "fechados", isto é, transformados em propriedade de uma minoria, obrigando assim os homens a procurarem "livremente" sustento junto aos proprietários. Cf. NIEBOER, Herman J. Slavery as an industrial system: ethnological researches. The Hage: Martinus Nijhoff, 1900. São bem conhecidos também os estudos de Karl Marx, relacionando a origem do trabalho assalariado à expropriação dos trabalhadores dos meios de produção. Cf. MARX, Karl. Formações econômicas pré-capitalistas. $7^{\mathrm{a}}$ ed. São Paulo: Paz e Terra, 2011, p. 65.

70 A partir de 1850, o endividamento conhecido como "aviamento", quando o patrão adiantava aos trabalhadores víveres e materiais de trabalho a valores impagáveis, disseminou-se pelas áreas de exploração de látex, ao longo dos anos do chamado boom da borracha. As disputas pelos locais de extração e controle da mão de obra também fizeram com que alguns proprietários, por exemplo, limitassem o acesso aos produtos de alguns rios, "fechando a sua foz". Cf. LEAL, Davi Avelino. Direitos e processos diferenciados de territorialização: os conflitos pelo uso dos recursos naturais no rio Madeira (1861-1932). Tese (doutorado em Sociedade e Cultura na Amazônia) - Instituto de Filosofia e Ciências Humanas, Universidade Federal do Amazonas, Manaus, 2013, p. $64-69,75-82$. 
Em 1848, dez anos após a criação dos Corpos de Trabalhadores, Jeronimo Francisco Coelho tentou rebater uma série de críticas que vinham sendo feitas à instituição. O presidente do Pará reconhecia, porém, o hábito dos comandantes em empregar "gratuitamente e com rigor a esses indivíduos no seu serviço particular ou no de seus amigos íntimos". Assim, a obrigação do trabalho, que teria surgido como "medida necessária e útil", tornara-se apenas "servidão odiosa". Entre as consequências mais perceptíveis, estaria o deslocamento de pessoas para territórios fronteiriços. Na região do "Lago Amapá" e nas proximidades com Caiena, na Guiana Francesa, existiriam verdadeiros "ninhos perigosos de malfeitores", congregando desertores, criminosos e outros foragidos, "entregues a uma vida semisselvagem e embrutecida, sem religião, sem moral, e sem lei". ${ }^{71}$

Entretanto, as censuras não eram exclusivamente direcionadas aos Corpos de Trabalhadores em si, mas à permanência de uma lei e práticas consideradas de "exceção" em tempos de aparente tranquilidade pública. Nesse contexto, a manutenção dos comandos militares também era malvista, devido ao grande número de atribuições e poderes que haviam recebido de Soares de Andrea. Por isso, Jeronimo Coelho sugeriu adaptar a instituição, reestruturando as forças provinciais paraenses, e transbformando os Corpos de Trabalhadores em "Companhias Municipais" ligadas à Guarda Nacional. Mas esta teria que ser reinstalada no Pará, por estar dissolvida na província desde 1835. Todavia, Coelho recebeu ordens para aguardar a reforma da Guarda Nacional em todo o reino, o que só ocorreria com a publicação da Lei N. ${ }^{\circ} 602$, de 19 de setembro de 1850 , quando o presidente já havia saído do governo. ${ }^{72}$

Dessa forma, a pretendida reorganização dos Corpos de Trabalhadores ocorreria somente em 15 de novembro de 1854, no governo de Sebastião do Rego Barros. Basicamente, esse presidente reuniu, num único regulamento, todas as legislações, instruções e portarias anteriores, adaptando e acrescentando detalhes que achou necessários, acerca das diferentes modalidades de engajamento e contratação de serviços públicos e particulares. ${ }^{73}$ Sua maior queixa, no entanto, era de que os alistamentos estavam sendo atrapalhados por "qualificações indevidas na Guarda Nacional". ${ }^{74}$ Isso porque os guardas nacionais não poderiam nem mesmo ser oficiais nos Corpos de Trabalhadores, embora os alistados nestes últimos pudessem compor a "milícia cidadã", desde que tivessem renda própria. ${ }^{75}$ De acordo com informações

71 Falla dirigida pelo exm. ${ }^{\circ}$ snr. Conselheiro Jeronimo Francisco Coelho, presidente da provincia do Gram-Pará, á Assembléa Legislativa Provincial na abertura da sessão ordinária da sexta legislatura no dia $1 .^{\circ}$ de outubro de 1848. Pará, Typographia de Santos \& Filhos, 1848, p. 32-33.

72 Relatorio feito pelo exm. ${ }^{\circ}$ sñr. Conselheiro Jeronimo Francisco Coelho, presidente desta provincia, e entregue ao $1 .^{\circ}$ vice presidente em exercicio, o exm. ${ }^{\circ}$ snr. dr. Angelo Custodio Corrêa, no dia $1 .^{\circ}$ de agosto de 1850. Pará, Typographia de Santos \& Filhos, 1850, p. 44-48.

73 Falla que o exm. ${ }^{\circ}$ snr. Conselheiro Sebastião do Rego Barros, prezidente desta província, dirigiu á Assembléa Legislativa Provincial na abertura da mesma Assembléa, no dia 15 de agosto de 1854. Pará, Typographia da Aurora Paraense, 1854, p. 51.

74 Exposição apresentada pelo senr. Conselheiro Sebastião do Rego Barros, presidente da província do Pará, por ocasião de passar a administração da mesma província ao $10^{\circ}$ vice-presidente o exm. ${ }^{\circ}$ senr. Dr. Angelo Custodio Corrêa. Pará: Typographia de Santos \& Filhos, 1855, p. 14.

75 Gazeta Official, edições de 27 set. 1858 e 10 nov. 1859, Biblioteca Nacional do Rio de Janeiro (BNRJ). 
colhidas junto aos comandantes, em toda a província existiam 4.402 trabalhadores, reunidos em nove Corpos. ${ }^{76}$

Finalmente, a principal instituição oficial de trabalho compulsório existente na Amazônia do século XIX teria seus momentos decisivos nos últimos anos da década de 1850. Em setembro de 1858, um projeto assinado por dez deputados da Assembleia Legislativa do Pará tinha como finalidade nada menos do que a extinção dos Corpos de Trabalhadores. A proposta, contudo, foi rejeitada pelo restante dos parlamentares..$^{77} \mathrm{Em}$ contrapartida, no ano seguinte, o presidente Manoel de Frias e Vasconcellos decidiu submeter à apreciação da Assembleia um plano de completa reforma dos Corpos e criação de uma Guarda Municipal. ${ }^{78}$

Porém, uma reviravolta surpreendente teria início pouco mais de duas semanas após o envio da fala do presidente. No dia 18 de outubro de 1859, um projeto assinado por 12 deputados propunha novamente a extinção dos Corpos de Trabalhadores em toda a província. ${ }^{79}$ Três dias depois, a Assembleia apresentou o seu parecer a respeito das propostas do presidente Vasconcellos. Sem eufemismos, o texto desconstruía as bases da reforma e criticava o que definia como um atentado "contra a inviolabilidade dos direitos civis e políticos do cidadão". Em conclusão, proferia que a Lei $\mathrm{N} .{ }^{\circ} 2$, de 1838 , deveria ser o "quanto antes revogada". ${ }^{80}$

Nas sessões seguintes, os deputados trocariam provocações sobre o que teria feito alguns deles mudarem de opinião acerca dos Corpos de Trabalhadores, considerando que muitos tinham votado contra um projeto igual àquele que um ano depois estavam dispostos a aprovar. ${ }^{81}$ Esses debates, entretanto, não atrapalharam o rápido encaminhamento dos trâmites. Assim, em menos de um mês, a Assembleia aprovou o projeto, e o presidente do Pará Antônio Coelho de Sá e Albuquerque sancionou a Lei N ${ }^{\circ} 330$, de 15 de novembro de 1859, cujo único artigo determinava serem "extintos os Corpos de Trabalhadores e revogadas todas as leis e disposições em contrário". ${ }^{82}$

As ideias sobre a extemporaneidade da lei de Soares de Andrea e os abusos dos comandantes militares, apesar de serem muito apropriadas como justificativa da decisão tomada pela Assembleia e o presidente, obliteravam a existência de uma estratégia de alcance muito maior, e que já tinha sido acertada entre o chefe do Executivo e vários membros do

76 Relatorio apresentado á Assembléa Legislativa Provincial do Pará no dia 15 de agosto de 1856, por occasião da abertura da primeira sessão da 10. ${ }^{a}$ legislatura da mesma Assembléa, pelo presidente, Henrique de Beaurepaire Rohan. Pará: Typographia de Santos \& Filhos, 1856, p. 9. Nota-se uma redução significativa de alistados, em relação aos 7.626 informados por Jeronimo Coelho, em 1849.

77 Gazeta Official, edições de 11 e 21 set. 1858, BNRJ.

78 Falla dirigida á Assembléa Legislativa da provincia do Pará na segunda sessão da XI legislatura pelo exm. ${ }^{\circ} \mathrm{sr}$. tenente coronel Manoel de Frias e Vasconcellos, presidente da mesma provincia, em 1. ${ }^{\circ}$ de outubro de 1859. Pará, Typographia Commercial de A.J.R. Guimarães, 1859, p. 49-52.

79 Assembléa Legislativa Provincial - Sessão ordinária em 18 de outubro de 1859, A Epocha, 3 nov. 1859, BNRJ. 80 Assembléa Legislativa Provincial - Sessão ordinária em 21 de outubro de 1859, A Epocha, 24 out. 1859, BNRJ.

81 Assembléa Legislativa Provincial - Sessão ordinária em 27 de outubro de 1859, A Epocha, 17 nov. 1859, BNRJ.

82 Lei N. ${ }^{\circ} 330$, de 15 de novembro de 1859. In: Collecção das Leis da Província do Gram-Pará. Belém: Typographia de Frederico Carlos Rhossard, tomo XXI [1859], parte I, 1862, p. 12-13, IHGB, PER 0.7.1-19. Gazeta Official, 19 nov. 1859, BNRJ. No Amazonas, contudo, os Corpos de Trabalhadores somente foram extintos em 1862, por meio da Lei Provincial N. ${ }^{\circ}$ 114, de 27 de maio. Cf. SAMPAIO, Patrícia Maria Melo. Os fios de Ariadne: tipologia de fortunas e hierarquias sociais em Manaus: 1840-1880. Manaus: EDUA, 1997, p. 109. 
Parlamento paraense. Na concepção destes, a crescente ocupação da área contestada com a França, ao norte da foz do rio Amazonas, as várias atividades e relações econômicas dessa população, e até a possibilidade da sua organização política ou anexação estrangeira exigiam que fossem tomadas providências sobre o assunto.

Em ofício confidencial dirigido ao ministro dos Negócios Estrangeiros, Antônio de Albuquerque informava que, desde o momento da sua posse, vinha atuando junto à Assembleia para a revogação da lei dos Corpos de Trabalhadores. Segundo o presidente, os alistamentos naquela instituição eram motivo de "queixas clamorosas da população menos civilizada e menos abastada", a qual preferia ausentar-se "da capital e de outras povoações para a região do Amapá, preferindo, assim, servir aos interesses dos franceses com prejuízo aos dos brasileiros". ${ }^{83}$ Em seguida, Antônio de Albuquerque esclarecia suas medidas e as expectativas a partir delas.

Extinguir os Corpos de Trabalhadores significava, para o presidente e os deputados, "tirar aos franceses da Guiana todo o pretexto de proteção aos súditos do Império ali [no Amapá] refugiados". O próximo passo, então, seria "atrair estes aos nossos interesses comerciais e políticos". ${ }^{44}$ Cumprida a primeira etapa, restaria então criar as condições para reconquistar a confiança daqueles homiziados na fronteira. Para isso, Antônio de Albuquerque mandou publicar em jornal a revogação da lei de 1838 e um texto escrito exclusivamente para as populações da região contestada, no qual assegurava garantias de livre circulação a todos os oriundos do Amapá.

O artigo, publicado na Gazeta Official, dizia que as autoridades de Macapá e Belém estavam terminantemente proibidas de recrutar qualquer "indivíduo que vier das costas do Norte", com a finalidade de comércio, ou que se empregasse "na salga de peixe, na extração da seringa e de óleo, ou na colheita de cacau, castanha etc.". Para ter direito a essa isenção, os moradores deveriam apresentar-se em uma daquelas cidades, onde receberiam uma guia, com a qual se poderia "entrar e sair em qualquer porto, rio ou lago, sem mais dependências e sem o menor receio de ser embaraçado". ${ }^{85} \mathrm{~A}$ única exceção era feita para os contrabandistas, que continuariam sujeitos a punições. $O$ texto ainda enfatizava que os trabalhadores e comerciantes do Amapá ${ }^{86}$ podiam aumentar seus lucros e benefícios negociando com a capital, enquanto Belém e sua vizinhança receberiam maiores quantidade de produtos, a preços menores.

83 Arquivo Histórico do Itamaraty. Ofício confidencial do presidente da província do Pará, Antônio Coelho de Sá e Albuquerque, ao secretário de Estado dos Negócios Estrangeiros, João Lins de Vieira Cansanção de Sinimbu, em 23 de novembro de 1859. Governo do Pará (Ofícios). Códice 308-4-4.

84 Ibidem.

85 Gazeta Official, 22 nov. 1859, BNRJ.

86 No século XIX, é comum encontrarmos em jornais e em correspondências de governo o termo "Amapá" referindo-se tanto à vila localizada próximo ao Cabo Norte quanto às terras da região do Contestado Franco-Brasileiro, ou mesmo a toda a vasta área entre o rio Amazonas e o Oiapoque. A história recente da unidade administrativa que originou o atual estado do Amapá remonta oficialmente ao ano de 1943, quando foi criado um território federal desmembrado do Pará durante o Estado Novo de Getúlio Vargas. Em 1988, o território tornou-se estado da Federação, preservando os limites geográficos estabelecidos na década de 1940. 
A combinação entre as querelas diplomáticas envolvendo Brasil e França sobre uma vasta área no extremo norte amazônico e as permanentes fugas, deserções e articulações sociais, políticas e econômicas envolvendo a população pobre livre, indígena e escrava havia atingido um ponto crítico na "região do Amapá". O reconhecimento dessa situação por parte de representantes do Estado brasileiro levou ao colapso do último instrumento oficial criado exclusivamente para a compulsão ao trabalho na Amazônia. Acima de tudo, o fim dos Corpos de Trabalhadores indicava o quanto as autoridades estavam constrangidas e pressionadas e certamente surpresas - pelas ações dos subalternos. ${ }^{87}$

\section{À guisa de conclusão: Amazônia, um labirinto com muitas entradas e saídas entre a escravidão e a liberdade}

HÁ MAIS DE TRÊS DÉCADAS, a historiografia do trabalho em âmbito internacional passou a debater com bastante ênfase os limites, entrelaçamentos e correlações entre o trabalho livre e o chamado "trabalho não livre". No início dos anos 1990, um editorial da International Review of Social History já chamava a atenção para o fato de que a ideia de trabalho livre, no sentido estritamente marxista, isto é, «por um lado 〈livre` dos meios de produção, e por outro 〈livre» de compulsões não econômicas ao trabalho» era historicamente "a exceção ao invés da regra". ${ }^{88}$ E nesse sentido, era forçoso reconhecer a existência de um "amplo espectro de formas intermediárias e mistas entre o puro trabalho livre assalariado e o trabalho completamente não livre". Logo, diferentes estudos têm insistido na coexistência, interdependência e convivência entre liberdade, escravidão e compulsoriedade, e até mesmo na ampliação de formas de trabalho não livre após o fim da escravidão formal. ${ }^{89}$

Desse modo, o termo unfree labor ("trabalho não livre") estabeleceu-se como uma categoria analítica internacionalmente utilizada pela historiografia para designar diferentes tipos de trabalho compulsório, independentemente do lugar ou período. Contudo, embora certamente inclua a escravidão, seu emprego tem sido cada vez mais comum em pesquisas que buscam superar as definições clássicas de escravidão e liberdade, consideradas formas extremas e rígidas demais para analisar determinadas especificidades históricas. Dentre esses dois polos, no entanto, é a noção de trabalho livre aquela que mais frequentemente tem sido objeto de problematizações e críticas, assim como os pressupostos teleológicos que

87 A respeito das relações entre o mundo do trabalho amazônico, comunidades de fugitivos e as querelas diplomáticas entre o Brasil e a França na Amazônia setentrional, ver PAZ, Adalberto Junior Ferreira. Repúblicas contestadas: liberdade, trabalho e disputas políticas na Amazônia do século XIX. Tese (doutorado em História) - Instituto de Filosofia e Ciências Humanas, Universidade Estadual de Campinas, Campinas, 2017.

88 Free and Unfree Labour. International Review of Social History, v. 35, i. 1, p. 1-2, apr. 1990.

89 Ver BRASS, Tom; LINDEN, Marcel van der (eds.), Free and unfree labour: the debate continues. Berne: Peter Lang AG, 1997. STEINFELD, Robert. Coercion, contract and free labor in the nineteenth century. Cambridge: Cambridge University Press, 2001. COOPER, Frederick; HOLT, Thomas C.; SCOTT, Rebecca J. Além da escravidão: investigações sobre raça, trabalho e cidadania em sociedades pós-emancipação. Rio de Janeiro: Civilização Brasileira, 2005. LINDEN, Marcel van der; GARCÍA, Magaly Rodríguez (eds.). On Coerced Labor: Work and Compulsion after Chattel Slavery. Leiden; Boston: Brill, 2016. 
afirmam a "evolução" inevitável de relações de trabalho escravistas para o trabalho capitalista assalariado.

Concomitantemente ao debate internacional sobre free e unfree labor, no Brasil avançavam os estudos sobre a história social da escravidão e a história social do trabalho. Em decorrência disso, a ampliação do escopo analítico suscitou críticas e reivindicação que pleiteavam a queda do chamado "muro historiográfico" que separava trabalhadores escravos e operários livres em áreas de pesquisa tratadas como fundamentalmente distintas. ${ }^{90}$ No ensejo, também se criticavam os recortes temporais tradicionais entre o Império e a República, que amparavam a chamada historiografia da transição do trabalho escravo para o trabalho livre. ${ }^{91}$

Não obstante essas revisões, a Amazônia permanecia de algum modo deslocada da historiografia nacional dominante, sobretudo, por dois motivos. Em primeiro lugar, devido à quantidade bem menos expressiva de escravos negros ali presente, em comparação a outras regiões como Bahia e Rio de Janeiro - apesar dos constantes esforços de diversas autoridades para reverter esse quadro, pelo menos desde o século XVII. ${ }^{92}$ Consequentemente, em segundo lugar, a ideia de uma "transição" entre escravidão e liberdade rumo ao estabelecimento de um operariado fabril igualmente não correspondia às peculiaridades e vicissitudes da história do trabalho na região.

Contudo, se por um lado a Amazônia careceria de elementos estruturais que garantissem sua plena adequação ao modelo escravista brasileiro, digamos, "clássico" sendo por isso considerada "exceção" -, o mesmo não ocorre quando contrapomos a região a outras sociedades coloniais ao redor do mundo, e até mesmo certos países europeus, tomando como referência os debates sobre trabalho livre e não livre. ${ }^{93}$ Assim, conforme o exposto, o que se observa na Amazônia é a manutenção secular de instrumentos oficiais de compulsoriedade para a maior parte da população não legalmente escravizada, por meio de incentivos, legislações e regulamentações estatais até meados do século XIX. Tais mecanismos e práticas institucionalizaram diferentes formas de exploração do trabalho apoiadas em múltiplas interseccionalidades relacionadas à cor, classe e etnia. O que reforça a importância de análises que perscrutem os vínculos, cruzamentos e a diversidade de experiências individuais e coletivas envolvendo índios, negros livres e libertos, e os pobres em geral.

Na Amazônia oitocentista, os dilemas entre o trabalho livre e não livre relacionavam-se a duas das questões mais longamente enfatizadas pelas elites da região, ou seja, as dificuldades

90 Ver a respeito GOMES, Flávio dos Santos; NEGRO, Antônio Luigi. Além das senzalas e fábricas: uma história social do trabalho. Tempo Social, revista de sociologia da USP, v. 18, n. 1, 2006.

91 Para um balaço crítico sobre a historiografia do trabalho no Brasil após a década de 1980, ver CHALHOUB, Sidney; SILVA, Fernando Teixeira da. Sujeitos no imaginário acadêmico: escravos e trabalhadores na historiografia desde os anos 1980. Cadernos AEL, v. 14, n. 26, 2009.

92 Ver CHAMBOULEYRON, Rafael. Escravos do Atlântico equatorial: tráfico negreiro para o estado do Maranhão e Pará (século XVII e início do século XVIII). Revista Brasileira de História, São Paulo, v. 26, n. 52, p. 79-114, dez. 2006.

93 Ver a respeito PAZ, Adalberto. Free and unfree labor in the nineteenth-century Brazilian Amazon. International Review of Social History, v. 62, Special Issue S25, p. 23-43, dec. 2017. 
na oferta da mão de obra escrava africana e a alegada escassez e demasiada autonomia dos braços "livres". Como vimos, a expectativa era de que, removidos os entraves, bastaria aumentar o quantitativo de escravos e providenciar para que os demais sujeitos desempenhassem seus papéis no processo de ocupação do vasto território amazônico. Entretanto, a incorporação dos índios à sociedade luso-brasileira jamais significou sua dispensa do cumprimento de atividades econômicas. De um jeito ou de outro, o trabalho indígena não livre estabeleceu-se como regra ao longo dos séculos, independentemente da sua condição legal.

Ao longo do século XIX, o avanço da ideologia de repressão à vadiagem e de uso do trabalho como instrumento de controle social influenciaram diretamente o tipo de liberdade que se dizia existir não apenas para os índios, mas também para os pobres livres, negros libertos e mestiços na Amazônia. Em poucas palavras, para os não escravos tratava-se de viver uma liberdade ameaçadoramente precária. ${ }^{94} \mathrm{E}$ isso não somente por práticas ilegais ou arbitrariedades, mas principalmente porque a classificação de indivíduos e grupos por meio de critérios socioeconômicos, incluindo o tipo de ocupação laboral e forma de sobrevivência, somados a marcadores étnico-culturais, tornava legalmente justificável a exploração do trabalho de forma compulsória de todos aqueles cujos designativos fossem considerados inapropriados, repreensíveis e até mesmo delituosos.

A possibilidade dos menos favorecidos dispensarem vínculos de dependência econômica, sobrevivendo dos variados recursos das florestas e rios, ou de se associarem conjuntamente para negar ou contornar o status quo baseado na dominação e exploração, igualmente influenciaram o surgimento de leis de coação ao trabalho. ${ }^{95}$ Assim, na tentativa de evitar ou eliminar a realização dessas alternativas às classes mais baixas, as elites econômicas e políticas da região amazônica frequentemente reforçaram seus mecanismos de imobilização e compulsoriedade.

A revogação da lei dos Corpos de Trabalhadores no Pará, em 1859, sugeria a aparente liberação definitiva de um enorme contingente populacional, historicamente submetido a uma longa tradição de compulsão ao trabalho. Contudo, durante a ascensão do chamado boom da borracha na Amazônia, na segunda metade do século XIX, outras formas de trabalho não livre

94 Sobre a "precarização da liberdade", especialmente de negros livres e libertos no Brasil, ver CHALHOUB, Sidney. Costumes senhoriais: escravização ilegal e precarização da liberdade no Brasil Império. In: Elciene Azevedo et al. Trabalhadores na cidade: cotidiano e cultura no Rio de Janeiro e em São Paulo, séculos XIX e XX. Campinas: Editora da Unicamp, 2009. CHALHOUB, Sidney. A força da escravidão: ilegalidade e costume no Brasil oitocentista. São Paulo: Companhia das Letras, 2012. MAMIGONIAN, Beatriz G. Africanos livres: a abolição do tráfico de escravos no Brasil. São Paulo: Companhia das Letras, 2017. Para uma análise acerca do impacto dessas questões no sistema legal e prisional brasileiro, ver BEATTIE, Peter M. Punishment in Paradise: Race, slavery, human rights, and a nineteenth-century Brazilian penal colony. Durham; London: Duke University Press, 2015.

95 A inter-relação entre abundantes recursos naturais (especialmente terras), escassez de mão de obra, a possibilidade efetiva de os pobres se retirarem para áreas remotas e inacessíveis e a instalação de regimes de trabalho compulsório tem sido, naturalmente, um tema central na literatura sobre trabalho não livre (e a resistência a ele). Ver, por exemplo, NIEBOER, op. cit. DOMAR, Evsey D. The Causes of Slavery or Serfdom: A Hypothesis. The Journal of Economic History, v. 30, n. 1, p. 18-32, mar. 1970. SCOTT, James C. The Art of Not Being Governed: An Anarchist History of Upland Southeast Asia. New Haven; London: Yale University Press, 2009. 
se desenvolveram, baseadas no endividamento, intimidação e "retenção" de trabalhadores pelos patrões, no interior da floresta. ${ }^{96}$ Dessa forma, o trabalho livre e não livre na Amazônia reestruturou-se novamente, visando atender às demandas de matéria-prima das modernas indústrias do capitalismo internacional.

Recebido em: 13/04/2020

Aprovado em: 13/05/2020

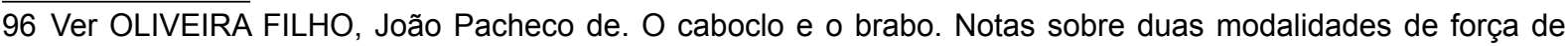
trabalho na expansão da fronteira amazônica no século XIX. Encontros com a Civilização Brasileira. V. 11, p. 101-140, 131-135, 1979. WEINSTEIN, Barbara. A borracha na Amazônia: expansão e decadência (18501920). São Paulo: Hucitec-Edusp, 1993. 